NBER WORKING PAPER SERIES

INVENTIVE ACTIVITY IN EARLY INDUSTRIAL AMERICA:

EVIDENCE FROM PATENT RECORDS, 1790 - 1846

Kenneth L. Sokoloff

Working Paper No. 2707

NATIONAL BUREAU OF ECONOMIC RESEARCH

1050 Massachusetts Avenue

Cambridge, MA 02138

September 1988

The author is grateful to Zorina Khan and James Lin for excellent research assistance, and to Francesca Bray. Paul David, Lance Davis, Stanley Engerman, Albert Fishlow, Claudia Goldin, Stephen Haber, Chris Hall, Steven Lubar, Douglass North, Nathan Rosenberg, Manuel Trajtenberg, Michael Waldman, Thomas Weiss, Finis Welch, Mary Yeager, and participants in seminars at the NBER, the Smithsonian Institution, Stanford Unfversity, UC Berkeley, UC Santa Cruz, UCIA, and the University of Hong Kong for valuable comments. He was a Fellow at the Center for Advanced Study in the Behavioral Sciences during 1987-88, and received support from the Center, the National Science Foundation, and the Institute of Industrial Relations and the Academic Senate at UCLA. This research is part of NBER's research program in the Development of the American Economy. Any opinions expressed are those of the author not those of the National Bureau of Economic Research. 
NBER Working Paper \#2707

September 1988

\section{INVENTIVE ACTIVITY IN EARLY INDUSTRIAL AMERICA: \\ EVIDENCE FROM PATENT RECORDS, 1790 - 1846}

\section{ABSTRACT}

A sample of patent records from the United States between 1790 and 1846 is employed to study the patterns in inventive activity. Patenting was pro-cyclical, and yet began to grow rapidly with the interruptions in foreign trade that preceded the war of 1812. A strong association between patenting and proximity to navigable waterways is also demonstrated. Although the importance of specific mechanisms remains unclear, both the temporal and cross-secticnal evidence imply that inventive activity was positively related to tlo growth of markets during early industrialization.

Kenneth L. Sokoloff

Department of Economics University of California Los Angeles, CA 90024 
Most scholars would agree that inventive activity is primarily responsible for the improvements in technology that are the basic contributor to sustained increase in per capita income. ${ }^{1}$ Yet, despite great interest in the onset and process of industrialization in the United States, there has been only limited study of the circumstances behind the sharp rise in the commitment of resources toward the discovery of new methods of production and the formulation of new products that was presumably at the root of this transformation. Indeed, virtually no systematic record of the trends or patterns in inventive activity during the crucial initial phase of growth has been available.

Not that the phenomenon of inventive activity in early industrial America has been ignored, for the subject has received serious attention from several groups of researchers. Perhaps most valuable are the richly detailed studies of the progression of technique in specific industries contributed by the histcrians of business and technology. ${ }^{2}$ These works contain a wealth of information, but although hypotheses about general patterns are often posed, their typical mode of investigation has been to illustrate theories with individual cases, rather than to explore their consistency with a large body of evidence.

Economic historians have also been concerned with the record of inventive activity during industrialization. The basis for their interest was elaborated by David Landes in his classic examination of the Industrial Revolution. Following a path blazed by Jacob Schmookler, Landes argued eloquently for the critical importance of demand, especially in this context of the early expansion of markets, in influencing both the level and 
direction of inventive activity. ${ }^{3}$ Critics of this view, such as Joel Mokyr and Nathan Rosenberg, have questioned the representativeness of the specific cases cited by Landes, offered counterexamples, and discussed in general the intellectual or technical interrelatedness of many inventions. ${ }^{4}$ Their principal objection is that prior to industrialization, the existing stock of knowledge allowed for only a very limited amount of further invention; since shifts in demand soon exhausted its modest potential, they alone cannot explain much of the progress or direction of change in technology during the era.

Much of the debate has been framed in terms of the relative importance of demand and supply in the British experience, but the same issues are relevant to the study of industrialization in the United States. Recent work on the record of productivity growth in early industrial America has found that rapid advances were realized by nearly all industries in the Northeast long before steam engines and highly mechanized manufacturing processes were widely diffused. It has been proposed that the beginning of this upsurge was powered by a general increase in the incentives to inventive activity that triggered improvements in the production of all sorts of outputs. ${ }^{5}$

One such broad stimulus to invention was the major growth in size and geographic extent of markets that marked the period, and is generally characteristic of the early stages of industrialization. This phenomenon would have directly spurred invention if the associated increase in demand faced by individual producers had boosted the perceived return to invention, and thereby encouraged the commitment of more inputs to the search for improved methods and products. ${ }^{6}$ other developments that might have 
accompanied the expansion of markets, including changes in cultural attitudes, learning-by-doing, the propensity to invest, information flows, the organizations of production, output mix, the degree of specialization, and the amount of resources available for inventive activity, could also have played important roles. Whatever the relative significance of these individual contributors, the possibility that the growth of markets served to ignite and redirect creative energy is of special interest because of its relevance for how economic advance became self-sustaining.'

The limited availability of evidence has prevented scholars from systematically studying the variation in inventive activity over time and place. ${ }^{8}$ In attempting to remedy the deficiency, this article follows the approach of Schmookler in employing a sample of patent records from the United States between 1790 and 1846. It describes the data and the workings of the patent system during that period in section II. In section III, the basic patterns in the variation of patents per capita over geographic unit and time are outlined, with particular attention devoted to the striking pro-cyclicality, as well as to the correspondence of the first major surge in patenting with the years of interruption in foreign trade just prior to the War of 1812 . It is argued that these features of the temporal record indicate that inventive activity was quite responsive to market demand during the era. In section IV, the cross-sectional variation across counties in patents per capita is examined, and a strong relationship between patenting and proximity to navigable inland waterways is demonstrated. Although the importance of specific mechanisms remains unclear, the evidence seems to suggest that the extension of the waterway network during the period stimulated significant increases in inventive 
activity. Section $V$ observes that the analyses of the temporal and cross-sectional patterns reinforce each other in implying that inventive activity was positively related to the growth in markets, and offers some conclusions about the bearing of the results on our understanding of early American industrialization.

This use of patent records to gauge inventive activity is based on an assumption that there existed, in the place and period under study, a reasonably regular relationship, on average, between the allocation of resources to the search for useful inventions and the acquisition of patents. Such a relationship may have varied between industries, over time, or across regions, but the presumption here is that much useful information can be extracted from the patterns in the data. Indeed, many investigators have employed patent records for this purpose and found them valuable as measures of inventive activity. ${ }^{9}$

The data consist of roughly 4,500 patents filed in the United States between 1790 and 1846, and were randomly drawn from several indexes prepared by the Commissioner of Patents. Included for each is a description of the invention or discovery patented, its industrial classification, the name and residence of the patentee, and the date the patent was granted. 10 other variables were constructed to supplement this information, such as the population and labor force allocation of the county in which the patentee resided, as well as various classifications of the invention by type or economic sector. The sample includes almost 30 percent of all patents filed over the period under study. 
The nature of the patent system changed significantly over these first 57 years of the nation. At the beginning, applications for patents were scrutinized carefully for novelty and usefulness, and were awarded jointly by the Attorney General, the Secretary of War, and the Secretary of State. This procedure, however, consumed much of the time of Thomas Jefferson, who held the latter cabinet position and primary responsibility for evaluating the applications, and it was altered within a few years. The new arrangement was a system of patent registration, characterized by essentially no inspection of the applications for either novelty or utility. For the most part, inventors appear to have simply registered their patents, while paying the rather substantial fee of $\$ 35 .^{11}$ The non-trivial cost presumably served to screen out many frivolous or valueless inventions.

This system of registration ultimately proved problematic as a means of protecting the property rights of inventors. By the 1830 s there was extensive litigation and widespread discontent with the process, apparenty stemming from the lack of attention to originality and technical detail in evaluating applications. At times, the courts recognized vaguely specified patents, and issued injunctions to stop the operations of firms utilizing any related technology. In other cases, they would hear challenges to patents based on other evidence concerning first discovery or use of an idea in determining who held the property rights to the income it generated. Many observers contended that the costs of enforcing these property rights were approaching levels that threatened the viability of the system, and inhibited inventive activity. In response, a fundamental change in the patent system was implemented on July 4th, 1836, whereby an office staffed by professionals with technical expertise was established to review 
applications systematically for novelty and usefulness. The impact was dramatic. From a situation in which virtually no complete applications were turned away, a major share, ranging from 20 to over 50 percent, came to be routinely rejected. A sharp decline in the number of patents filed was the immediate short-run effect, but it was later reversed as the volume of applications and filings began to surge again during the mid-1840s. ${ }^{12}$

It is clear that at least this one institutional change, the change of law in 1836, seriously altered the relationship between the level of inventive activity taking place and the number of patents awarded. The exact dating of this break in the pattern facilitates adjustments in the analysis, but other sources of shift or variation in the relationship between inventive activity and patenting may not be so easy to allow for. Such complicating factors do not, however, constitute an insurmountable obstacle to the use of patent records for studying inventive activity. Patents reflect a meaningful, even if small, proportion of the total amount of inventive activity carried out, and much of their variation mirrors corresponding differences in the resources devoted to invention. Where alternative explanations of the patterns in patenting emerge, they can be examined in the particular context.

II I

The United States was well endowed for invention and growth from the outset of the nation. Not only was the economy primed with rich supplies of natural resources and an educated populace, but its institutions provided considerable freedom for individual enterprise. Moreover, Americans of the Early Republic were aware of the economic transformation that had recenty 
begun in England, and of the advances in technology that accompanyied that process. The response to these propitious conditions was strong, and although a precise record is beyond our capabilities at this point, it is clear that sustained economic growth got under way early in the nineteenth century. It is, therefore, not surprising that the plots presented in Figure 1 , of the national total of patents awarded and the number included in the sample, indicate a substantial increase in inventive activity over the period from 1790 to 1846. Patents far outpaced population, with the per capita number rising nearly 500 percent.

Perhaps less expected, however, is that the growth in total patents was not continuous, but rather concentrated in two intervals that accounted for virtually all of the progress realized over the entire period. The first upswing began in the late 1790 s and continued through 1812 . It coincided with a span of prosperity that was ostensibly broken by a series of disruptions to foreign commerce induced by British interference with shipping lanes and the Embargo of 1807 . After peaking in 1812 , the number of patents granted each year dropped somewhat, and remained on a plateau through the War of 1812 and the long contraction that followed the peace. The second phase of extended advance ran from the economic revival in the early 1820 s to July 1836 , when the patent law was changed to tighten the requirements for awards. With the introduction of new standards, the volume plunged and then stabilized for nearly a decade at a lower level before turning up in 1846. One might be tempted to ascribe this spell of stagnation, evident in both applications and issues, to uncertainty about the unfamiliar system. However, another prolonged slowdown in business activity, which began in 1837 and persisted until just before the end of the 


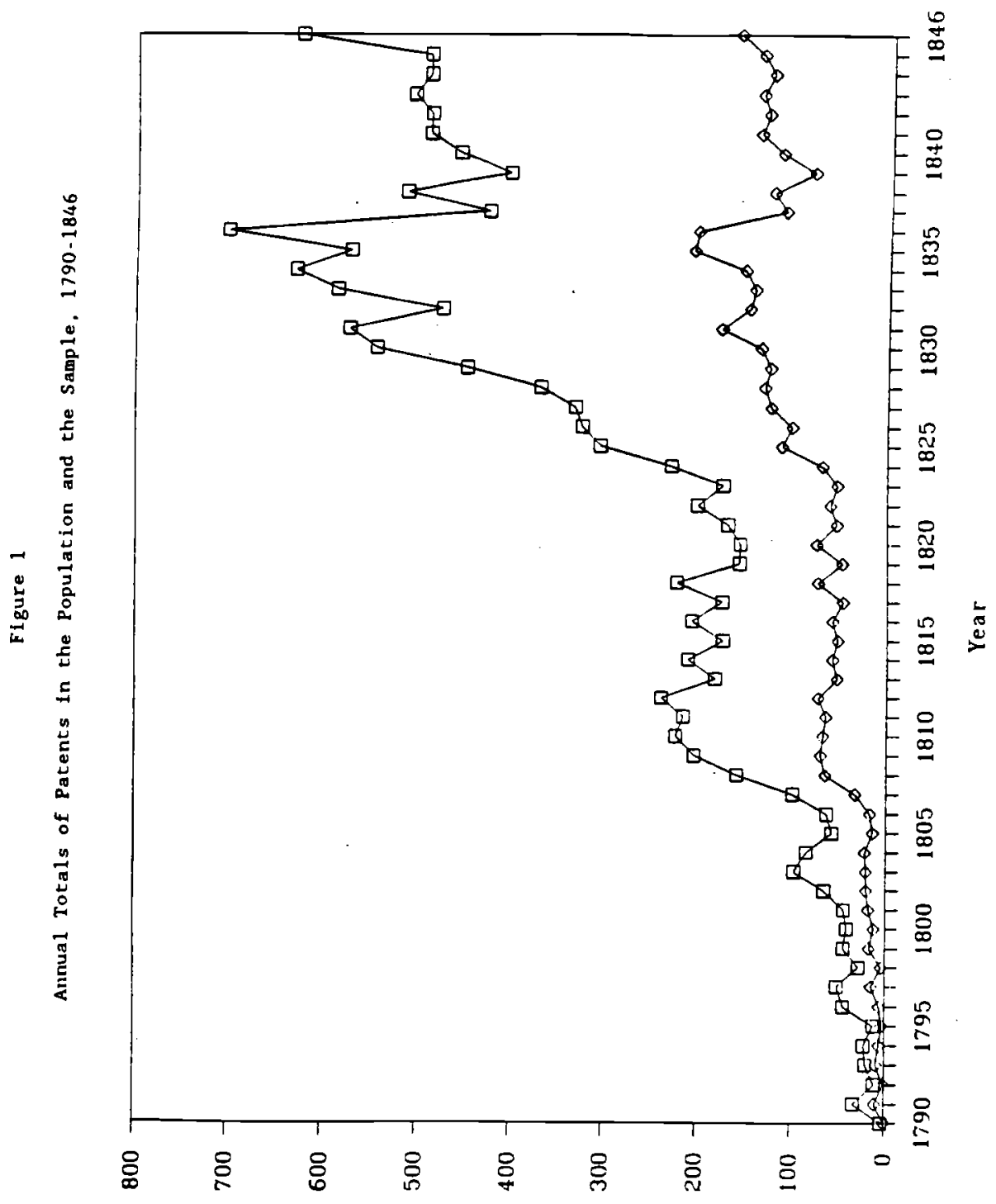

patif stuajed 
Notes and Sources:

The upper plot reports the total muber of patents issued in the U.S. during the respective years. See linited States Bureau of the Census, Historical Statistics of the United States, Colonial Times to 1970 (Washington, D.C., 1975), Series $6-99$. The lower plot reports the number of patents in the sample for the respective years; note that the year-to-year fluctuations in the two plots correspond rather well. The sample, drawn from the indexes described in footnore 10 . comprises just under 30 percent of the patents filed between 1790 and 154 in inclusive. Due to the sample being drawn from two indexes. the percentage of patents sampled for 1839.46 was somewhat lower than for the previous years. This plot of sample frequencies is unweighted, and accordingly seems to account for a smaller proportion of the total in those years. All of the results reported in the remainder of the paper, however, are based on analyses of data weighted to account for this inadvertent salipling variation. 
period, must also have borne some responsibility.

Although time series regressions sustain the strong relationship between patenting and business conditions over annual data, the evidence for pro-cyclicality is most compelling when the era is divided into the sub-periods suggested above. It is hard to reject as coincidental the observation that patenting grew rather steadily throughout the period except for the two intervals of protracted economic contraction, 1815-1822 and 1837-1843. ${ }^{13}$ Given that these were the only downturns of such duration, the synchronization appears especially telling. There were several one- or two-year drops in patenting not obviously associated with a business cycle, as well as various abbreviated cyclical declines that seem not to have produced decreases in the numbers of patents awarded. However, rieither phenomenon warrants rejecting the hypothesis of pro-cyclical behavior. ${ }^{14}$ Using Schmookler's framework, one can explain the correspondence between patenting and business conditions through the increase in the expected return to an invention that occurs with the number of units over which the advance can be applied. Hence, the level of resources devoted to the search for a particular invention would grow with the size of the market for the relevant output, and inventive activity in general would increase with either cyclical or secular expansion of the economy. ${ }^{15}$ There are, of course, alternative theories. For example, it might be suggested that fluctuations in inventive activity drove the business cycles. Besides the questionable strength of any such effect in the context of an early industrial economy, however, the experience during the sub-period of the Embargo appears to contradict this conjecture. Another possibility is that the growing economy generated more resources for inventive activity, and 
thus the number of patents rose accordingly. Given the surge in patents during the Embargo, as well as the much more rapid rise of patenting than of national income or investment, this explanation would require an extraordinarily high income elasticity of invention.

The cyclicality in patenting is generally robust across regions and economic sectors of the country, as indicated in Table 1 where estimates of the annual patent rates, classified by sector, are reported for various regions of the Northeast, and the rest of the United States. Patenting is expressed on a per capita basis, as it is in the remainder of the paper, because measures normalized for population size are more meaningful for a study of how individuals behaved; eight sub-periods have been specified, with the particular dates selected to delineate intervals marked by relevant events or cyclical activity. Although there are differences within the Northeast in the level of patenting and the character of the cycles, the cyclicality apparent in the national totals is quite general. There are significant deviations, but most seem readily accounted for. Due probably to the stimulus of the building of the Erie Canal, for example, patenting in New York boomed during 1823-1829, and its growth slackened in 1830-1836, whereas the record in Southern New England was reversed.

The cyclical swings in the other regions, which lagged far behind New York and Southern New England in achieving high levels of patenting per capita, are not as pronounced, but the discrepancies may be attributable to regional variation in business cycles or secular trends. Regional differences in the timing of major transportation projects, the integration of markets, and the pace of economic growth might have moderated the influence of national cycles in cases such as Pennsylvania and the Southern 
Table 1

Annual Patent Rates Per 1,000,000 Residents, by Sector and Region

\begin{tabular}{|c|c|c|c|c|c|c|c|c|}
\hline & $\begin{array}{l}1791- \\
1798\end{array}$ & $\begin{array}{l}1799- \\
1804\end{array}$ & $\begin{array}{c}1805 \\
1811\end{array}$ & $\begin{array}{c}1812 . \\
1822\end{array}$ & $\begin{array}{c}1823 \\
1829\end{array}$ & $\begin{array}{l}1830 \\
1836\end{array}$ & $\begin{array}{l}1836- \\
1842\end{array}$ & $\begin{array}{l}18+3 \\
18+6\end{array}$ \\
\hline \multicolumn{9}{|l|}{ Agricuiture } \\
\hline ‥ New Eng & 0.7 & 1.9 & 2.2 & +1 & 9.6 & 15.8 & 6.8 & 3.5 \\
\hline S. New Eng & 00 & 1.3 & 10.9 & 6.5 & 7.9 & 8.4 & 12.6 & 4.5 \\
\hline Sew York & 0.0 & 3.4 & 13.3 & 12.7 & 15.2 & 20.2 & 6.8 & 106 \\
\hline Pennsylvania & 15 & 0.0 & 32 & 3.6 & 7.3 & 11.9 & 6.3 & +6 \\
\hline S. Mid Atl & 0.5 & 3.8 & 4.6 & 4.7 & 6.5 & 6.8 & 148 & 46 \\
\hline Other L'. S. & 0.5 & 0.2 & 1.5 & 1.4 & 4.1 & 3.6 & 1.7 & 4.4 \\
\hline VATIONAL & 0.5 & 1.3 & 4.6 & 4.2 & 6.9 & 8.3 & 4.6 & 5.2 \\
\hline \multicolumn{9}{|l|}{ Construction } \\
\hline Y. New Eng. & 0.0 & 1.1 & 4.9 & 1.7 & 3.8 & 15.5 & 8.0 & 3.5 \\
\hline S. New Eng. & 2.4 & 9.0 & 16.3 & 7.9 & 10.1 & 22.8 & 6.6 & 6.0 \\
\hline New York & 3.6 & 4.6 & 12.6 & 6.0 & 13.0 & 23.1 & 12.4 & 6.9 \\
\hline Pennsylvania & 1.8 & 1.8 & 6.5 & 5.2 & 3.6 & 9.0 & 5.4 & 4.1 \\
\hline S. Mid Atl. & 0.0 & 1.8 & 3.4 & 4.8 & 4.6 & 7.0 & 8.2 & 4.6 \\
\hline Other C.S. & 0.2 & 0.2 & 0.5 & 1.2 & 1.5 & 2.5 & 1.7 & 1.1 \\
\hline NATIONAL & 1.0 & 2.4 & 5.2 & 3.2 & 4.8 & 8.9 & 4.6 & 2.9 \\
\hline \multicolumn{9}{|l|}{ Manufacturing } \\
\hline N. New Eng. & 1.1 & 4.5 & 7.3 & 6.8 & 10.5 & 24.0 & 14.2 & 9.6 \\
\hline S. New Eng. & 24 & 11.2 & 27.8 & 31.2 & 31.8 & 59.9 & $\$ 2.2$ & $\$ 9.6$ \\
\hline New York & 6.0 & 5.6 & 26.6 & 17.5 & 37.7 & 32.2 & 15.8 & 32.2 \\
\hline Pennsylvania & 7.0 & 10.0 & 16.2 & 15.5 & 13.8 & 21.3 & 9.7 & 20.0 \\
\hline S. Mid Atl. & 2.1 & 8.8 & 12.3 & 13.2 & 10.4 & 14.1 & 7.8 & 19.5 \\
\hline Other L. S. & 0.0 & 2.2 & 1.0 & 2.0 & 3.0 & 4.0 & 2.2 & 2.7 \\
\hline NATIONAL & 20 & 5.7 & 10.7 & 9.7 & 12.5 & 16.1 & 8.7 & 12.9 \\
\hline \multicolumn{9}{|l|}{ Transportation } \\
\hline V. New Eng. & 0.0 & 0.0 & 0.8 & 1.3 & 1.2 & 7.5 & 2.3 & 2.6 \\
\hline S. New Eng. & 1.2 & 3.0 & 6.0 & 5.6 & 4.0 & 6.9 & 13.0 & 33 \\
\hline New York & 1.2 & 0.9 & 4.1 & 8.6 & 10.5 & 11.2 & 11.3 & 95 \\
\hline Pennsylvania & 3.5 & 0.9 & 2.6 & 3.5 & 4.7 & 5.8 & 9.4 & 92 \\
\hline S. Mid Atl. & 1.4 & 0.9 & 2.7 & 7.6 & 6.4 & 8.2 & 8.2 & 102 \\
\hline Other U. S. & 0.5 & 0.5 & 0.5 & 1.2 & 1.1 & 1.4 & 1.6 & 门9 \\
\hline NATIONAL & 1.1 & 0.9 & 2.0 & 3.4 & 3.4 & 4.6 & 4.9 & 40 \\
\hline \multicolumn{9}{|l|}{ ALL SECTORS } \\
\hline Y. New Eng. & 1.9 & 7.5 & 15.2 & 15.1 & 33.0 & 65.5 & 32.9 & 20.0 \\
\hline S. New Eng. & 7.2 & 26.7 & 66.2 & 55.4 & 60.4 & 106.4 & 79.5 & $i 45$ \\
\hline New York & 10.9 & 16.4 & 62.0 & 49.9 & 81.3 & 95.6 & 49.6 & 6.58 \\
\hline Pennsylvania & 17.2 & 14.5 & 29.7 & 33.6 & 32.2 & 53.3 & 32.9 & $\$ 2.5$ \\
\hline S. Mid Atl. & 4.1 & 17.0 & 23.7 & 34.9 & 31.9 & 41.4 & 40.8 & 400 \\
\hline Other U. S. & 1.2 & 3.4 & 3.4 & 6.1 & 10.4 & 13.2 & 7.7 & 99 \\
\hline VATIONAL & 5.2 & 11.3 & 23.9 & 22.9 & 30.0 & $\$ 1.8$ & 24.5 & 273 \\
\hline
\end{tabular}


Notes and Sources;

The figures for the residual Eifth sector are not reported separately. See the note to Appendix Tables 1 and 2. 
Middle Atlantic during the 1815-1822 downturn. 16

Although the degree of cyclicality in patenting did vary somewhat, the basic pattern of pro-cyclicality also holds across sectors. Patents in construction manifest a marked sensitivity to business cycles, consistent with the recognized greater cyclical volatility of the industry. At the other extreme, patents in transportation, an industry in which one might expect secular trends to dominate, seem to have been relatively impervious to cyclical disturbances. Despite these contrasts in cyclical responsiveness, the five sectors shared fairly equally in the growth of inventive activity over time. Indeed, so similar were the secular trends at the national level that, as seen in Table 2, the sectoral distribution of patents changed only marginally over the period as a whole. ${ }^{17}$

Cross-sectional patterns can also yield information about the conditions associated with increases in patenting. There are enormous differences across regions, with all of the areas within the Northeast persistently registering higher levels of inventive activity than the rest of the nation. Perhaps even more interesting, however, is the substantial variation within that part of the country. Pennsylvania began the $1790 \mathrm{~s}$ as the leader, but Southern New England and New York participated disproportionately in the rapid growth of patenting during the first decade of the century, and came to far surpass all other regions in each sectoral classification. ${ }^{18}$ So outstanding were the two regions that by $1805-1811$ they had attained levels of patents per capita that were higher than any reached by their counterparts throughout the era. Only Northern New England, which realized a sharp upswing during the late 1820 s and early 1830 s, came close to matching their performance. 
Table 2

Sectoral Patent Shares, by Region

\begin{tabular}{|c|c|c|c|c|c|c|c|c|}
\hline & $\begin{array}{c}1791- \\
1798 \\
\varnothing\end{array}$ & $\begin{array}{c}1799- \\
1804 \\
o b\end{array}$ & $\begin{array}{c}1805- \\
1811 \\
o b\end{array}$ & $\begin{array}{c}1812- \\
1822 \\
\%\end{array}$ & $\begin{array}{c}1823 \\
1829 \\
\omega_{6}\end{array}$ & $\begin{array}{c}1830- \\
1836 \\
\text { of }\end{array}$ & $\begin{array}{c}1836- \\
1842 \\
\text { of }\end{array}$ & $\begin{array}{c}18+3 \\
18+6 \\
\text { of }\end{array}$ \\
\hline \multicolumn{9}{|l|}{ Agriculture } \\
\hline Y Vew Eng & 40.0 & 25.0 & 14.3 & 27.1 & 29.0 & 24.2 & 20.7 & 17.4 \\
\hline S. New Eng & $\ldots$ & 4.7 & 16.7 & 11.8 & 13.1 & 7.9 & 15.8 & 6.1 \\
\hline New York & $\cdot \cdot$ & 20.8 & 21.4 & 25.5 & 18.7 & 15.8 & 13.7 & 16.1 \\
\hline Pennsylvania & 8.5 & $\cdot \cdot$ & 10.9 & 10.6 & 22.5 & 22.3 & 19.1 & 10.8 \\
\hline S. Mid Atl. & 11.8 & 22.4 & 19.2 & 13.3 & 20.5 & 16.5 & 36.2 & 11.6 \\
\hline Other C.S. & +3.7 & 7.1 & 43.8 & 23.2 & 39.5 & 27.2 & 21.6 & $4+3$ \\
\hline NATIONAL & 10.0 & 11.3 & 19.2 & 18.2 & 22.9 & 19.8 & 18.9 & 19.2 \\
\hline \multicolumn{9}{|l|}{ Construction } \\
\hline N. New Eng & -- & 15.0 & 32.1 & 11.2 & 26.6 & 23.6 & 24.4 & 17.4 \\
\hline S. New Eng. & 33.3 & 33.6 & 25.0 & 14.3 & 16.7 & 21.4 & 8.3 & 8.1 \\
\hline New York & 33.3 & 28.3 & 20.4 & 12.1 & 15.9 & 24.2 & 24.9 & 10.6 \\
\hline Pennsylvania & 10.2 & 12.5 & 21.7 & 15.4 & 11.1 & 16.9 & 16.4 & 9.6 \\
\hline S. Mid Atl. & -. & 10.3 & 14.4 & 13.7 & 14.5 & 17.0 & 20.0 & 11.6 \\
\hline Other U.S. & 18.8 & 7.1 & 14.1 & 18.9 & 14.1 & 192 & 21.6 & 11.3 \\
\hline NATIONAL & 18.8 & 21.0 & 21.7 & 14.1 & 15.9 & 21.3 & 18.9 & 10.5 \\
\hline \multicolumn{9}{|l|}{ Manufacturing } \\
\hline N. New Eng. & 60.0 & 60.0 & +8.2 & 44.9 & 32.0 & 36.7 & 43.1 & 47.8 \\
\hline S. New Eng. & 33.3 & 42.1 & 42.6 & 56.3 & 52.6 & 56.3 & 53.1 & 66.7 \\
\hline New York & 55.6 & 34.0 & +2.9 & 35.1 & 46.3 & 33.7 & 32.0 & +89 \\
\hline Pennsylvania & 40.7 & 68.8 & 54.3 & 46.2 & 43.0 & 39.9 & 29.6 & 470 \\
\hline S. Mid Atl. & 52.9 & 31.7 & 51.9 & 37.6 & 32.5 & 34.0 & 19.0 & +8.8 \\
\hline Other $L^{*} . S$. & -. & 64.3 & 28.1 & 31.9 & 291 & 30.7 & 29.0 & 270 \\
\hline NATIONAL & 39.4 & 50.3 & $\$ 4.7$ & 42.1 & 41.7 & 38.6 & 35.6 & 471 \\
\hline \multicolumn{9}{|l|}{ Transportation } \\
\hline V. New Eng. & -- & -- & 5.4 & 8.4 & 3.6 & 11.4 & 6.9 & 13.0 \\
\hline S. New Eng. & 16.7 & 11.2 & 9.3 & 10.2 & 6.7 & 6.5 & 16.3 & 11.1 \\
\hline New York & 11.1 & 5.7 & 7.1 & 17.3 & 12.9 & 11.7 & 22.8 & 14.4 \\
\hline Pennsylvania & 20.3 & 6.3 & 8.7 & 10.3 & 14.8 & 10.8 & 28.5 & 21.7 \\
\hline S. Mid Atl. & 35.3 & 5.2 & 11.5 & 21.7 & 19.9 & 19.8 & 20.0 & 25.6 \\
\hline Other U.S. & 37.5 & 14.3 & 9.4 & 18.9 & 10.2 & 10.9 & 20.5 & 8.7 \\
\hline VATIONAL & 20.6 & 8.2 & 8.6 & 14.9 & 11.4 & 10.9 & 20.1 & 14.5 \\
\hline
\end{tabular}

Notes and Sources:

See the notes to Tabl: and Appendix Tables 1 and 2 . 
There were glimmerings of these regional disparities in 1799-1804, but the full-blown phenomenon did not materialize until the Embargo sub-period of 1805-1811. By then, patents per capita in Southern New England and New York had increased by 806 and 469 percent respectively over the previous decade, to levels two to four times those in other parts of the Northeast, and roughly twenty times that of the rest of the country. The obvious questions are: why did such a radical expansion of inventive activity occur then; why was it concentrated in Southern New England and New York; and why did the resulting inter-regional differentials persist? A valuable clue comes from the observations that the superiority of Southern New England and New York extended across all sectors, and that when patenting did significantly increase in other regions, it was generally associated with a similarly broad and discontinuous advance. The abruptness of the changes seems inconsistent with a relatively slowly-evolving aspect of the environment, such as culture, being responsible. Moreover, the range of sectors affected implies that the salient factor was not specific to a narrow set of industries. Accordingly, if the underlying catalyst was a breakthrough in knowledge, it must have been remarkably general in scope. Especially given the deficiencies of the alternatives, the most likely candidate for the source of the spurt in 1805-1811 is the changes in market demand stimulated, if not produced, by the suspension of foreign trade. ${ }^{19}$

Even accepting that the interruptions in foreign trade were crucial in setting off this early surge in invention, one is left to explain why Southern New England and New York responded most strongly at first, and were able to maintain their dominance over time. Evidently their resource endowments had prepared them better for the growth in domestic manufactures 
and enterprise engendered by the effective insulation from the previously dominant foreign competition. One way in which they were better positioned is that their populations were more concentrated in large cities. Since metropolitan centers were relatively rich in location-specific factors conducive to high rates of inventive activity, such as information flows and entrepeneurs, their larger population shares in New York and Southern New England might have helped account for the inter-regional differentials in patenting. 20

Indeed, the estimates of patents per capita by urbanization class reported in Table 3 do indicate huge disparities in the levels of inventive activity between metropolitan centers and other counties. This metropolitan advantage held across individual sectors (see the figures for manufacturing and agriculture in the Appendix), and peaked in 1805-1811 before the onset of a gradual erosion over time. Even as late as the 1830s, however, Boston and Philadelphia exhibited levels of patents per capita that were two to four times as high as those prevailing in the urban and rural counties of their respective regions. Given that such stark discrepancies were common between metropolitan and adjacent counties, they are difficult to rationalize as due to differences in product markets, and must surely be related to some fixed or slowly-evolving location-specific factors.

Despite the impressive creativity of their populations, the evidence reveals that all the world was not Philadelphia, New York, or even Boston. The large inter-regional differences first materialized in 1805-1811, when major increases in patenting occurred in many parts of Southern New England and New York but were essentially confined to metropolitan centers in other areas. Rural counties in these two regions raised their patent rates by 
Table 3

Decadal Patent Rates Per 1,000,000 Residents, by Sub-Region

\begin{tabular}{|c|c|c|c|c|c|c|c|c|}
\hline & $\begin{array}{l}1791- \\
1798\end{array}$ & $\begin{array}{c}1799- \\
1804\end{array}$ & $\begin{array}{l}1805- \\
1811\end{array}$ & $\begin{array}{l}1812- \\
1822\end{array}$ & $\begin{array}{l}1823- \\
1829\end{array}$ & $\begin{array}{l}1830 . \\
1836\end{array}$ & $\begin{array}{l}1836- \\
1842\end{array}$ & $\begin{array}{l}1843- \\
1846\end{array}$ \\
\hline \multicolumn{9}{|l|}{ Northern New England } \\
\hline Rural & 0.7 & 4.5 & 13.0 & 15.4 & 33.8 & 69.1 & 28.1 & 16.3 \\
\hline Urban & .. & -. & 9.8 & 11.4 & 9.9 & 50.2 & 42.1 & 27.6 \\
\hline Metro & -- & -- & -- & -. & -- & -- & -- & -- \\
\hline TOTAL & 1.9 & 7.5 & 15.2 & 15.1 & 33.0 & 65.5 & 32.9 & 20.0 \\
\hline \multicolumn{9}{|l|}{ Southern New England } \\
\hline Rural & 2.0 & 7.5 & 68.7 & 51.1 & 61.9 & 65.4 & 49.9 & 45.9 \\
\hline Urban & 0.0 & 22.4 & 34.6 & 37.9 & 44.0 & 106.3 & 68.8 & 57.0 \\
\hline Metro & 11.9 & 78.5 & 291.5 & 244.9 & 160.0 & 226.9 & 213.9 & 265.5 \\
\hline TOTAL & 7.2 & 26.7 & 65.2 & 55.4 & 60.4 & 106.4 & 79.5 & 74.5 \\
\hline \multicolumn{9}{|l|}{ New York } \\
\hline Rural & 0.0 & 0.8 & 46.6 & 32.5 & 56.5 & 72.0 & 20.8 & 23.6 \\
\hline Urban & 12.3 & 15.3 & 33.3 & 39.7 & 86.5 & 62.1 & 34.4 & 54.1 \\
\hline Metro & 24.8 & 68.0 & 121.4 & 116.0 & 159.7 & 196.7 & 131.9 & 148.4 \\
\hline TOTAL & 10.9 & 16.4 & 62.0 & 49.9 & 81.3 & 95.6 & 49.6 & 6.5 .8 \\
\hline \multicolumn{9}{|l|}{ Pennsyluania } \\
\hline Rural & 0.0 & 0.0 & 11.9 & 11.3 & 20.3 & 38.1 & 18.8 & 22.8 \\
\hline Urban & 0.0 & 8.6 & 17.3 & 8.7 & 8.4 & 31.4 & 20.7 & 22.1 \\
\hline Metro & 63.4 & 6.7 & 122.2 & 162.1 & 118.7 & 140.7 & 98.3 & 130.9 \\
\hline TOTAL & 17.2 & 14.5 & 29.7 & 33.6 & 32.2 & 53.3 & 32.9 & 42.5 \\
\hline \multicolumn{9}{|l|}{ Southern Middle Atlantic } \\
\hline Rural & 0.9 & 6.0 & 7.8 & 19.9 & 17.7 & 17.3 & 29.2 & 8.9 \\
\hline Urban & 4.8 & 11.9 & 12.3 & 20.6 & 8.0 & 21.1 & 24.1 & 47.1 \\
\hline Metro & 17.6 & 35.2 & 131.7 & 108.7 & 105.6 & 134.4 & 82.1 & 111.8 \\
\hline TOTAL & 4.1 & 17.0 & 23.7 & 34.9 & 31.9 & 41.4 & 40.8 & 40.0 \\
\hline Other U.S. & 1.2 & 3.4 & 3.4 & 6.1 & 10.4 & 13.2 & 7.7 & 9.9 \\
\hline NATIONAL AVERAGE & 5.2 & 11.3 & 23.9 & 22.9 & 30.0 & 41.8 & 24.5 & 27.3 \\
\hline
\end{tabular}


Notes and Sources:

See the note to Appendix $T$ ables 1 and 2. 
well over 800 percent between 1799-1804 and 1805-1811, while analogous jumps in patenting in the rest of the Northeast, such as the leap in Northern New England from a base of 15.1 in $1812-1822$ to 33.0 in $1823-1829$ and 65.5 in 1830-1836, were not realized until the 1820 s or later. ${ }^{21}$ The magnitude and persistence of the resulting disparities in non-metropolitan patenting are sufficient to explain much of the regional dominance of New York and Southern New England. Indeed, accounting decompositions indicate that, throughout the period, up to 80 percent of their advantage in regional figures was due to their higher patent rates in both rural and urban counties - as opposed to differences in metropolitan rates or distributions of population. 22

Not only was variation in patenting across non-metropolitan counties important in accounting for inter-regional differences, but invention from these districts made a significant contribution to national invention. As is apparent from the distributions of patents and populations reported in Table 4, citizens of large cities registered a highly disproportionate share of patents. Since the non-metropolitan counties retained the great bulk of the population, however, their patents were cumulatively more substantial. In 1805-1811 and 1830-1836, for example, the residents of non-metropolitan counties received over 65 and 70 percent respectively of the Northeast's patents, with those in New York and Southern New England alone filing roughly 40 percent of the national total in both sub-periods. At the very least, these figures indicate that developments in non-metropolitan areas played a central role in the growth of inventive activity during the critical early stages of American industrialization. They also suggest how much of the process is missed by a narrow focus on urban centers. 
Table 4

Distribution of Patents and Population

\begin{tabular}{|c|c|c|c|c|c|c|c|c|c|c|c|c|c|c|}
\hline $\begin{array}{l}1791 . \\
1798\end{array}$ & \multicolumn{2}{|c|}{$\begin{array}{l}1799- \\
1804\end{array}$} & \multicolumn{2}{|c|}{$\begin{array}{l}1805- \\
181 i\end{array}$} & \multicolumn{2}{|c|}{$\begin{array}{l}1812 . \\
1822\end{array}$} & \multicolumn{2}{|c|}{$\begin{array}{l}1823- \\
1829\end{array}$} & \multicolumn{2}{|c|}{$\begin{array}{l}1830- \\
1836\end{array}$} & \multicolumn{2}{|c|}{$\begin{array}{l}1836- \\
18+2\end{array}$} & \multicolumn{2}{|c|}{$\begin{array}{l}18+3 \\
18+6\end{array}$} \\
\hline $\begin{array}{l}\text { क } \\
\text { ats Pop }\end{array}$ & $\begin{array}{c}\infty 8 \\
\text { Pats }\end{array}$ & $\begin{array}{l}\text { कo } \\
\text { Pop }\end{array}$ & Pats & Pop & $\begin{array}{c}\% \\
\text { Pats }\end{array}$ & $\begin{array}{l}\text { of } \\
\text { Pop }\end{array}$ & $\begin{array}{l}\% \\
\text { Pats }\end{array}$ & $\begin{array}{c}\% \\
\text { Pop }\end{array}$ & $\begin{array}{c}\% \\
\text { Pats }\end{array}$ & Pop & $\begin{array}{c}\% \\
\text { Pats }\end{array}$ & $\begin{array}{c}\text { of } \\
\text { Pop }\end{array}$ & $\begin{array}{c}\infty \\
\text { Pats }\end{array}$ & Pop \\
\hline
\end{tabular}

Vorthern New

England

$\begin{array}{lllllllllllllllll}\text { Rural } & 1.3 & 8.7 & 3.7 & 9.2 & 4.5 & 8.2 & 5.2 & 7.8 & 7.7 & 6.9 & 9.0 & 5.4 & 5.2 & 4.6 & 2.6 & 4.3\end{array}$

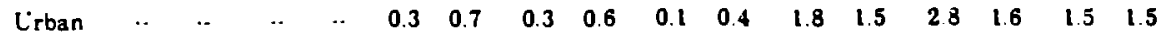

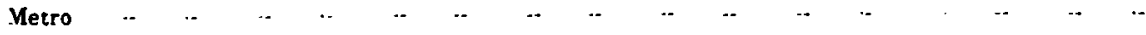

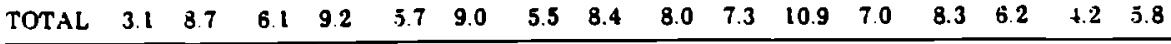

Southern.Vew

England

$\begin{array}{lllllllllllllllll}\text { Rural } & 5.6 & 14.2 & 7.9 & 11.9 & 19.2 & 6.7 & 10.8 & 4.8 & 9.1 & 4.4 & 2.5 & 1.6 & 2.2 & 1.1 & 1.7 & 1.0\end{array}$

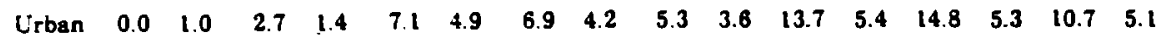

$\begin{array}{lllllllllllllllll}\text { Metro } & 1.9 & 0.8 & 3.7 & 0.5 & 6.1 & 0.5 & 5.1 & 0.5 & 2.6 & 0.5 & 2.8 & 0.5 & 4.9 & 0.6 & 5.7 & 0.6\end{array}$

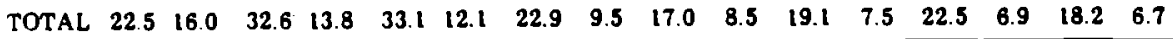

New York

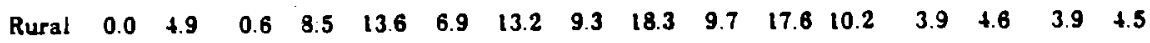

$\begin{array}{lllllllllllllllll}\text { Ćrban } & 1.9 & 0.8 & 0.9 & 0.7 & 3.7 & 2.6 & 4.2 & 2.5 & 6.0 & 2.1 & 3.2 & 2.2 & 10.0 & 7.1 & 129 & 6.5\end{array}$

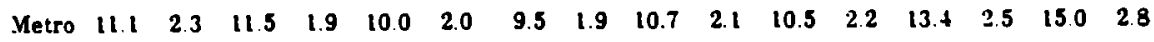

\begin{tabular}{llllllllllllllllll} 
TOTAL & 16.9 & 8.0 & 16.2 & 11.1 & 30.0 & 11.6 & 29.6 & 13.6 & 37.4 & 13.8 & 33.4 & 14.6 & 28.7 & 14.2 & 33 & 13.8 \\
\hline
\end{tabular}

Pennsyluania

$\begin{array}{lllllllllllllllll}\text { Rural } & 0.0 & 8.1 & 0.0 & 8.6 & 4.3 & 8.6 & 3.3 & 6.6 & 4.9 & 7.3 & 6.3 & 6.9 & 5.1 & 6.6 & 5.3 & 6.4\end{array}$

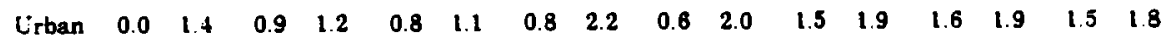

$\begin{array}{lllllllllllllllll}\text { Metro } & 18.8 & 1.5 & 0.9 & 1.5 & 8.1 & 1.6 & 10.6 & 1.5 & 5.8 & 1.5 & 5.0 & 1.5 & 6.1 & 1.5 & 7.7 & 1.6\end{array}$

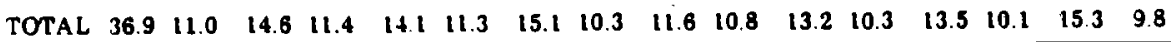

\section{Southern}

Hiddle Atlantic

$\begin{array}{lllllllllllllllll}\text { Rural } & 1.9 & 10.4 & 4.6 & 8.7 & 2.3 & 7.2 & 5.1 & 5.9 & 2.7 & 4.7 & 1.5 & 3.5 & 3.6 & 3.0 & 0.9 & 2.8\end{array}$

$\begin{array}{lllllllllllllllll}\text { Ċrban } & 1.9 & 2.0 & 1.8 & 1.7 & 1.1 & 2.2 & 1.6 & 1.7 & 0.4 & 1.4 & 0.8 & 1.6 & 1.3 & 1.4 & 2.6 & 1.5\end{array}$

$\begin{array}{lllllllllllllllll}\text { Metro } & 3.8 & 1.1 & 4.3 & 1.4 & 7.1 & 1.3 & 6.4 & 1.3 & 4.6 & 1.3 & 3.8 & 1.2 & 3.6 & 1.1 & 4.4 & 1.1\end{array}$

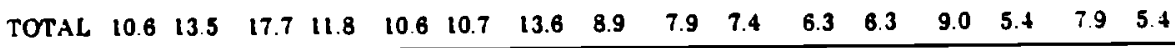

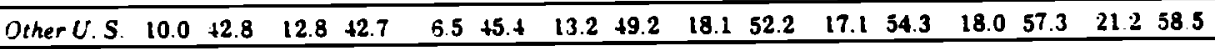

.VATIONAL $100.0100 .0 \quad 100.0100 .0 \quad 100.0100 .0 \quad 100.0100 .0 \quad 100.0100 .0 \quad 100.0100 .0 \quad 100.0100 .0 \quad 100.0100 .0$ TOTAL 
Notes and Sources:

See the note to the tables in the Appendix. Within each cell, the first figure is the estimated percentage of all U.S. patents issued during the respective sub-period that originated from the respective geographic area. Because of the many observations before 1810 that did not contain information on city of residence, the percentages accounted for by the urbanization classes may sum to less than the regional total. The second flgure is the percentage of the U.S. population that was estimated to reside in that geographic area at the mid-point of the sub-period. 
Variation in inventive activity over place and time was due to many factors, but an association between patenting and low costs of transportation to major markets is one pattern that stands out from an examination of the maps presented in Figures 2 through 5. As illustrated for 1805-1811 and 1830-1836, virtually all of the counties in the Northeast with high patenting rates were either metropolitan centers or in close proximity to a navigable waterway. This finding suggests a link between patenting and access to extensive markets, because waterways were the only means of low-cost transportation over long hauls until the late 1830s, when railroads first became a feasible alternative.

The two cross-sections alone provide strong evidence, but the changes over time indicate that the relationship held dynamically as well. During 1805-1811, the non-metropolitan districts with high patenting per capita were almost exclusively in or near the valleys of navigable segments of major rivers such as the Connecticut and the Hudson. By 1830-1836, this network of waterways had been much extended by canals and other improvements, opening up more areas to extensive markets, and the geographic extent of greater inventive activity had expanded concomitantly. Perhaps the most vivid example is New York (Figure 4), where the completion of the Erie Canal in 1825 seems to have sparked alterations of output mix and a sharp rise in patenting along its route. Northern New England is another region in which a remarkable advance in patenting between 1805-1811 and 1830-1836 appears related to extensions of waterways. Whereas no county in New Hampshire or Vermont (Figure 5) exhibited substantial inventive activity in 1805-1811, two decades of building canals on the Connecticut and the 


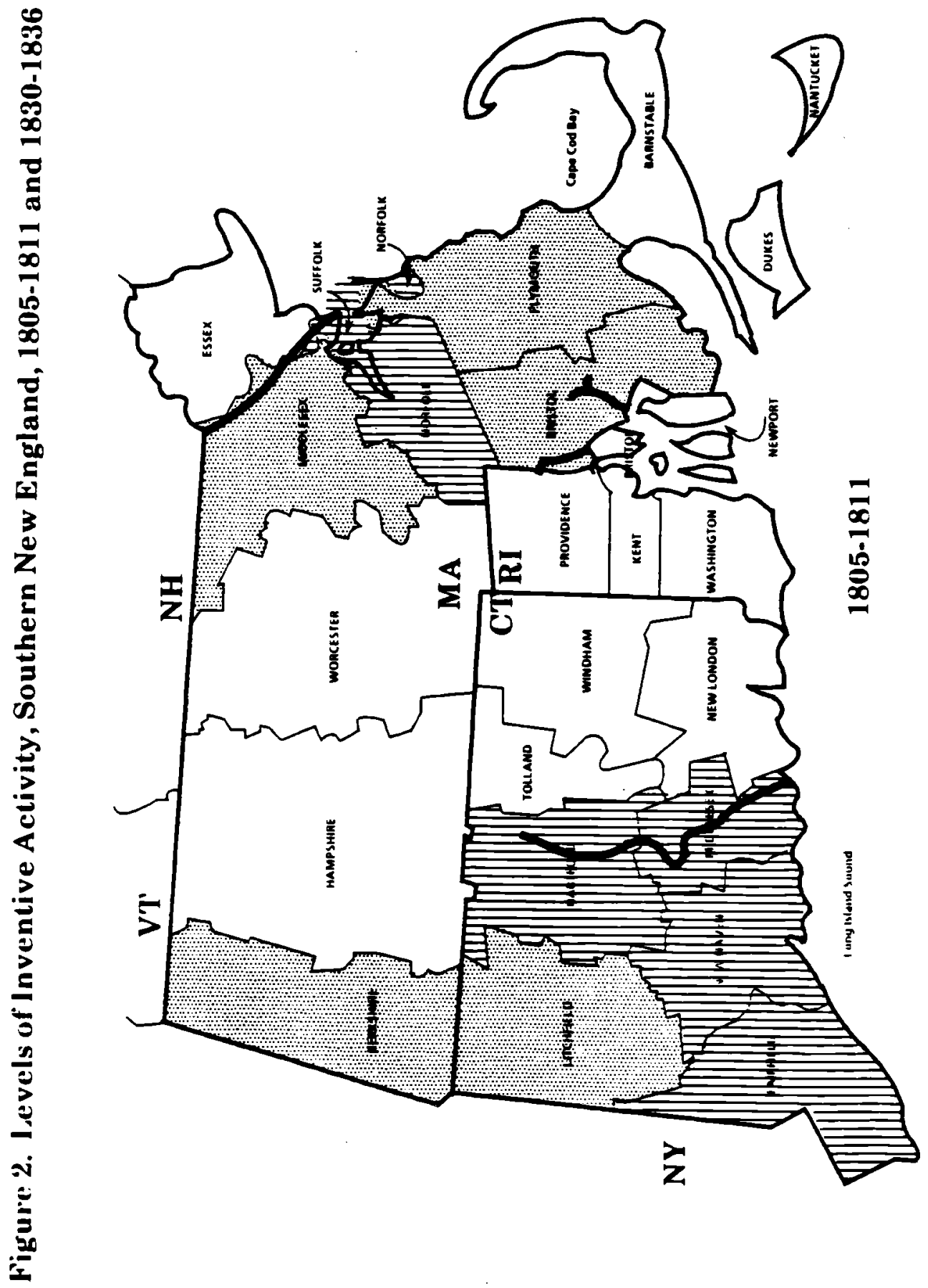




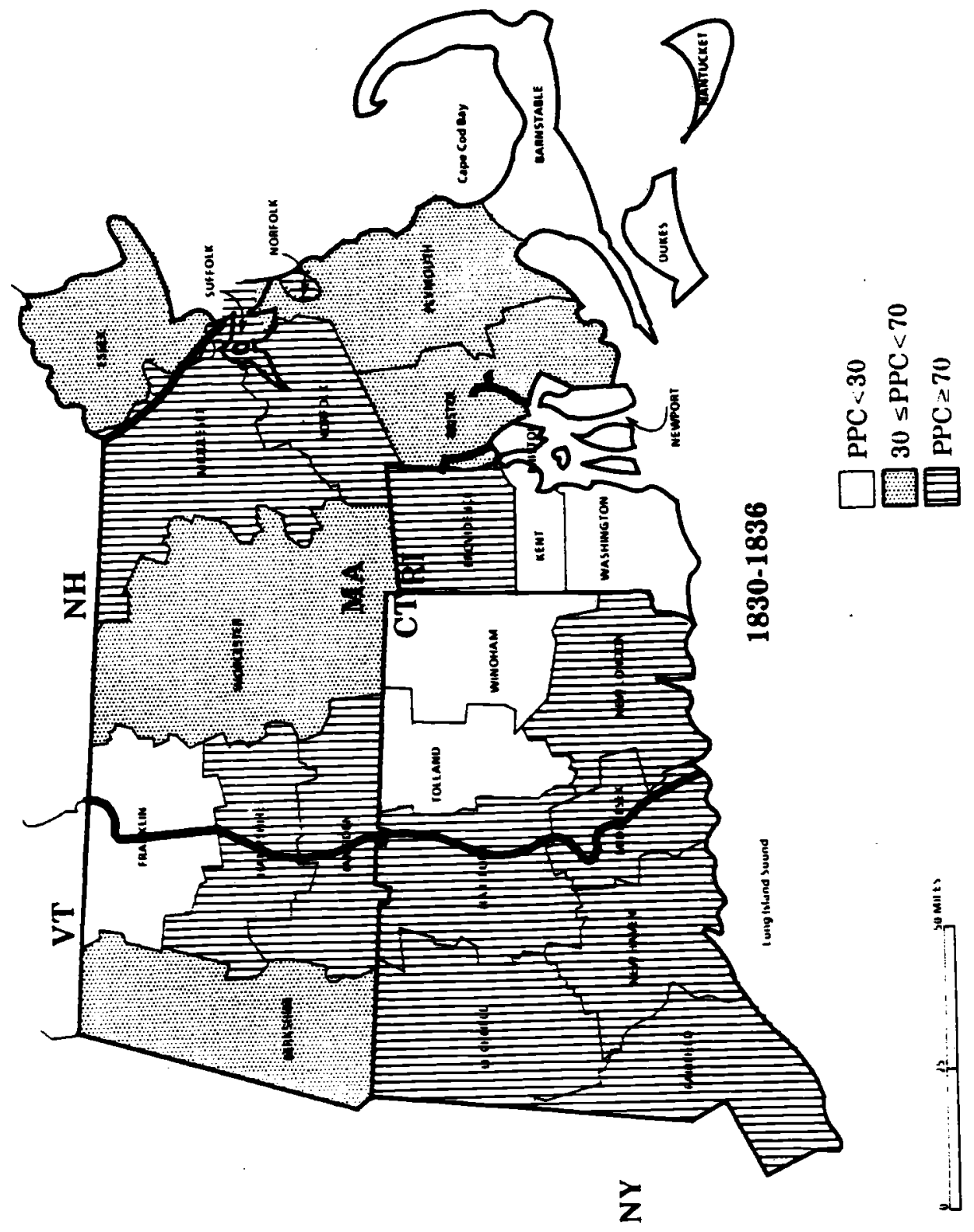




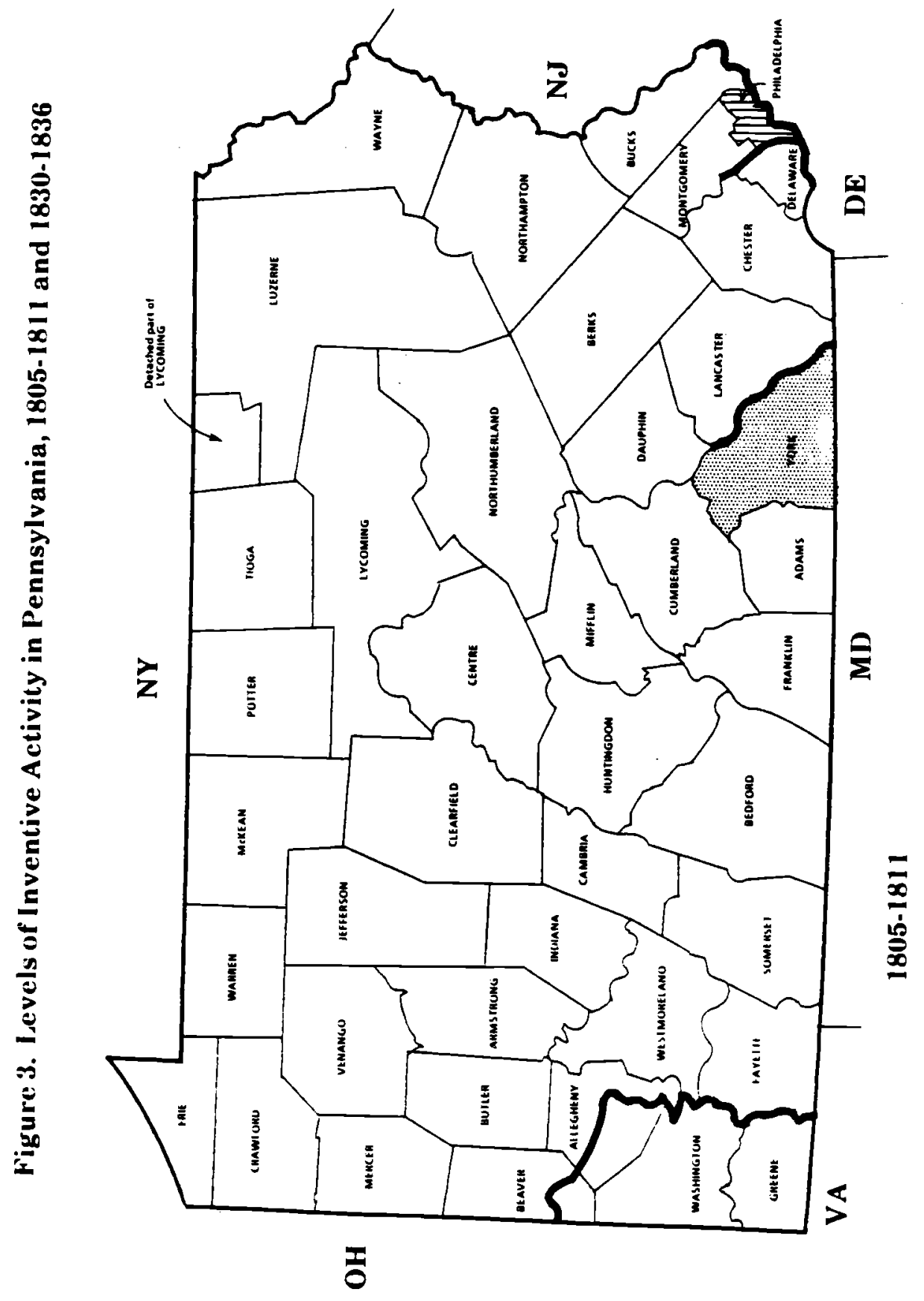




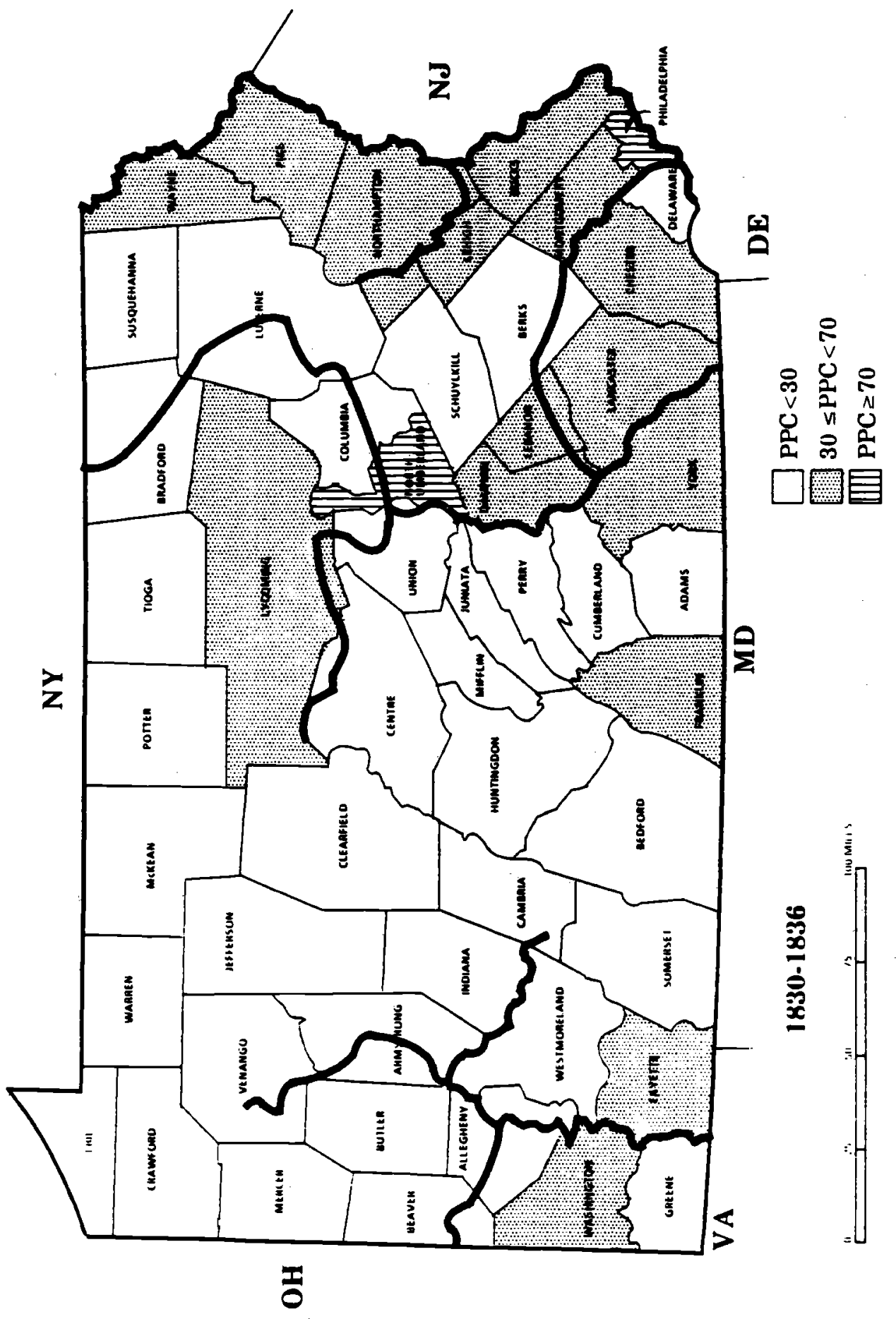




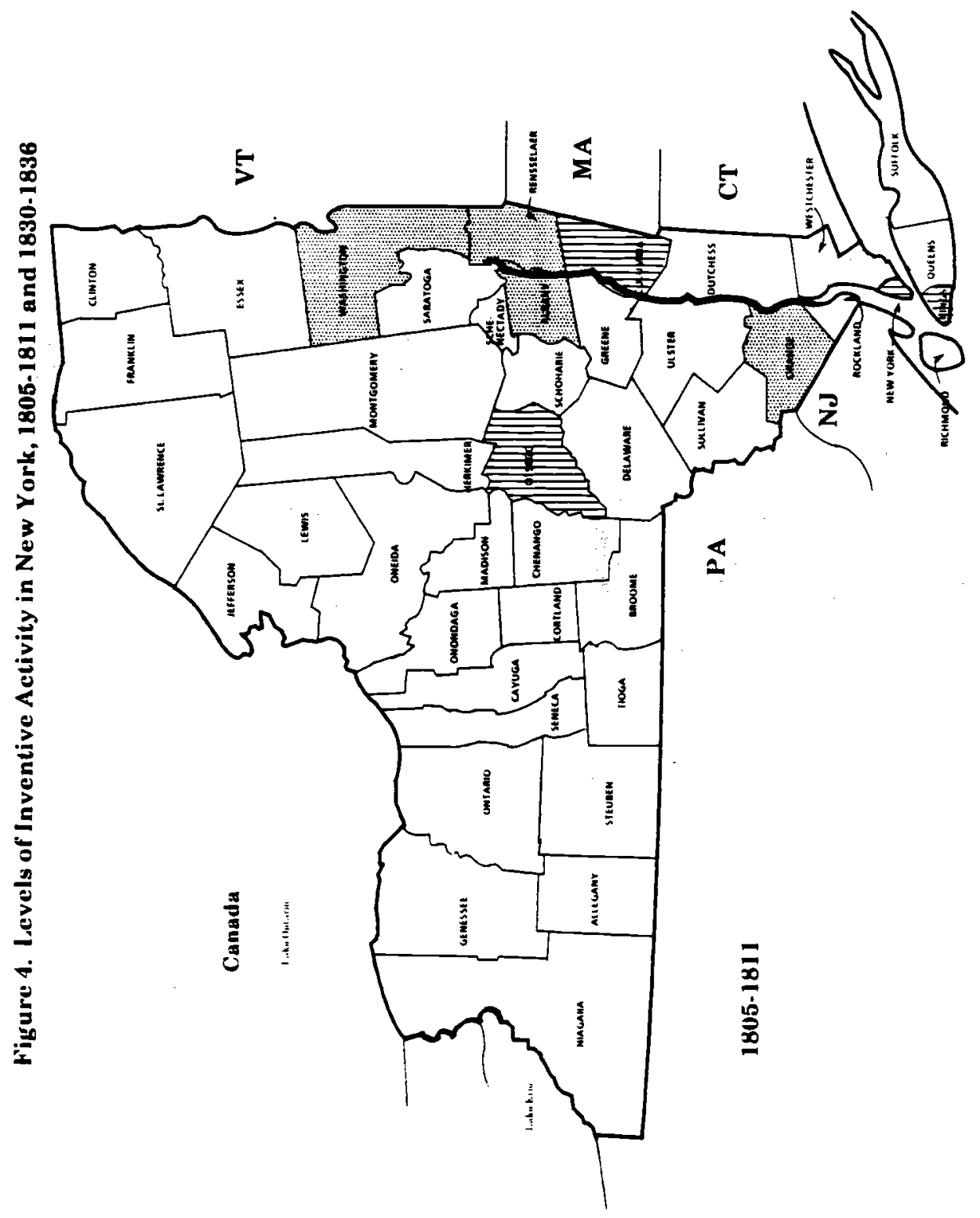




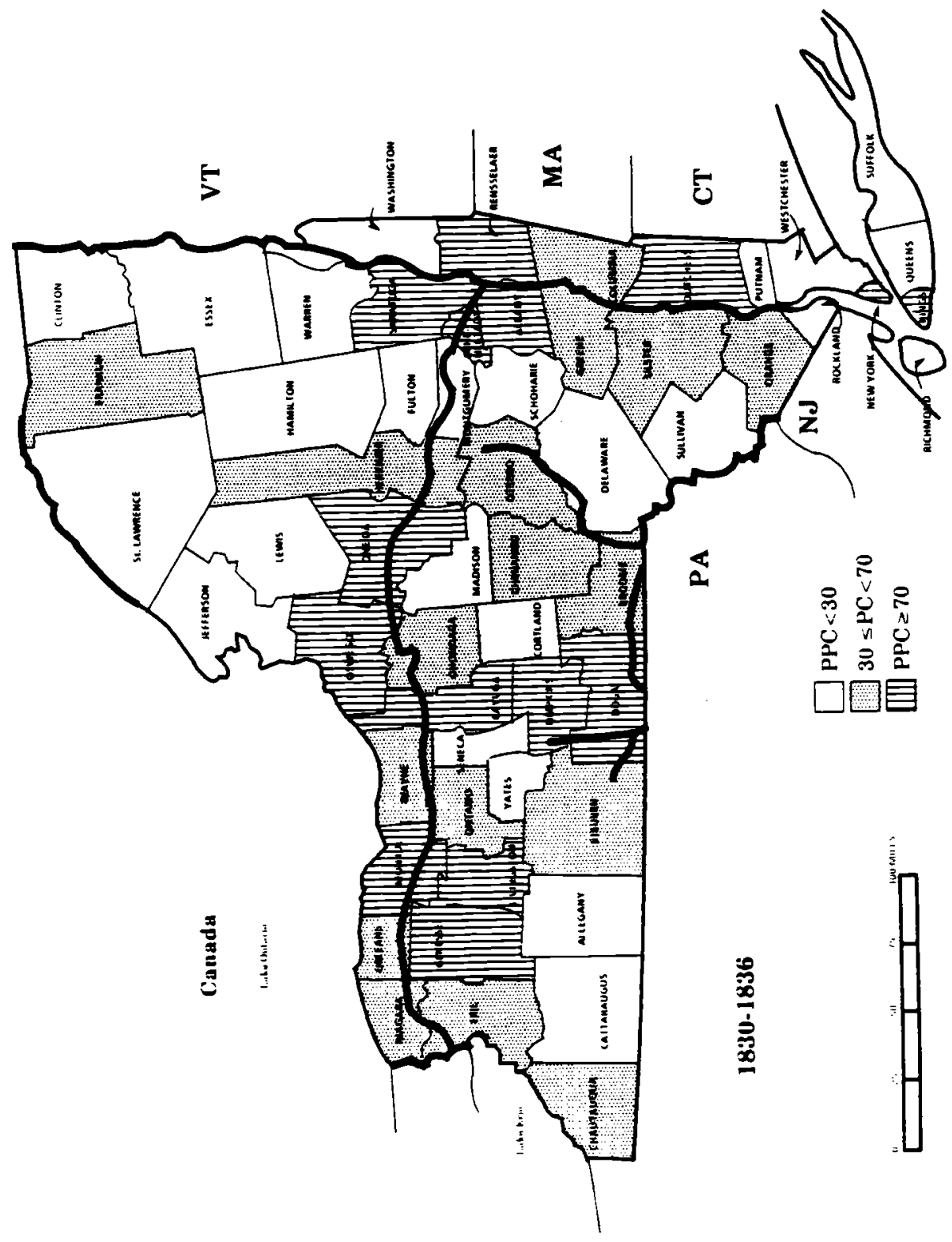


Figure 5. Levels of Inventive Activity, New Hampshire and Vermont, 1805-1811 and 1830-1836

$1805-1811$

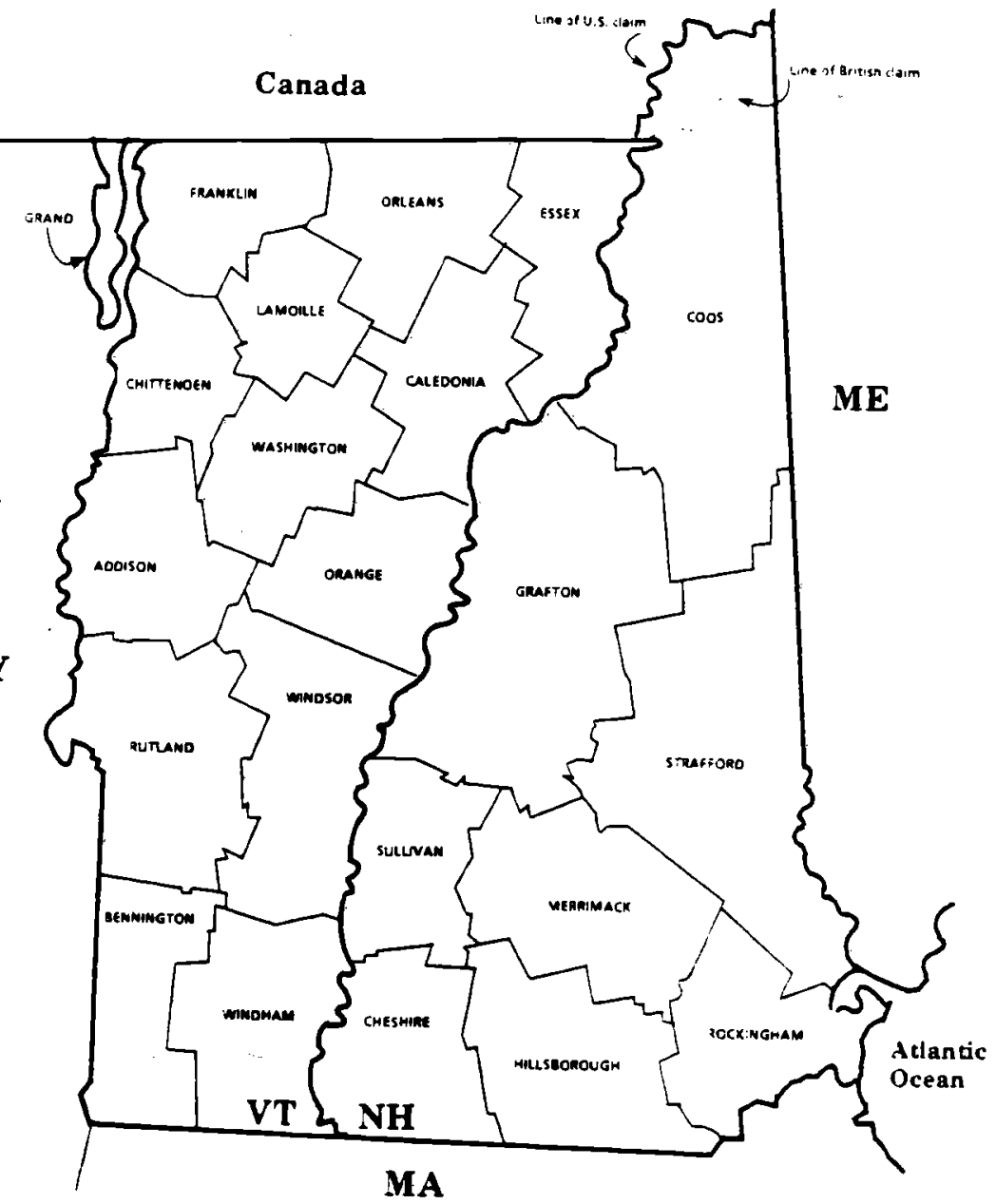




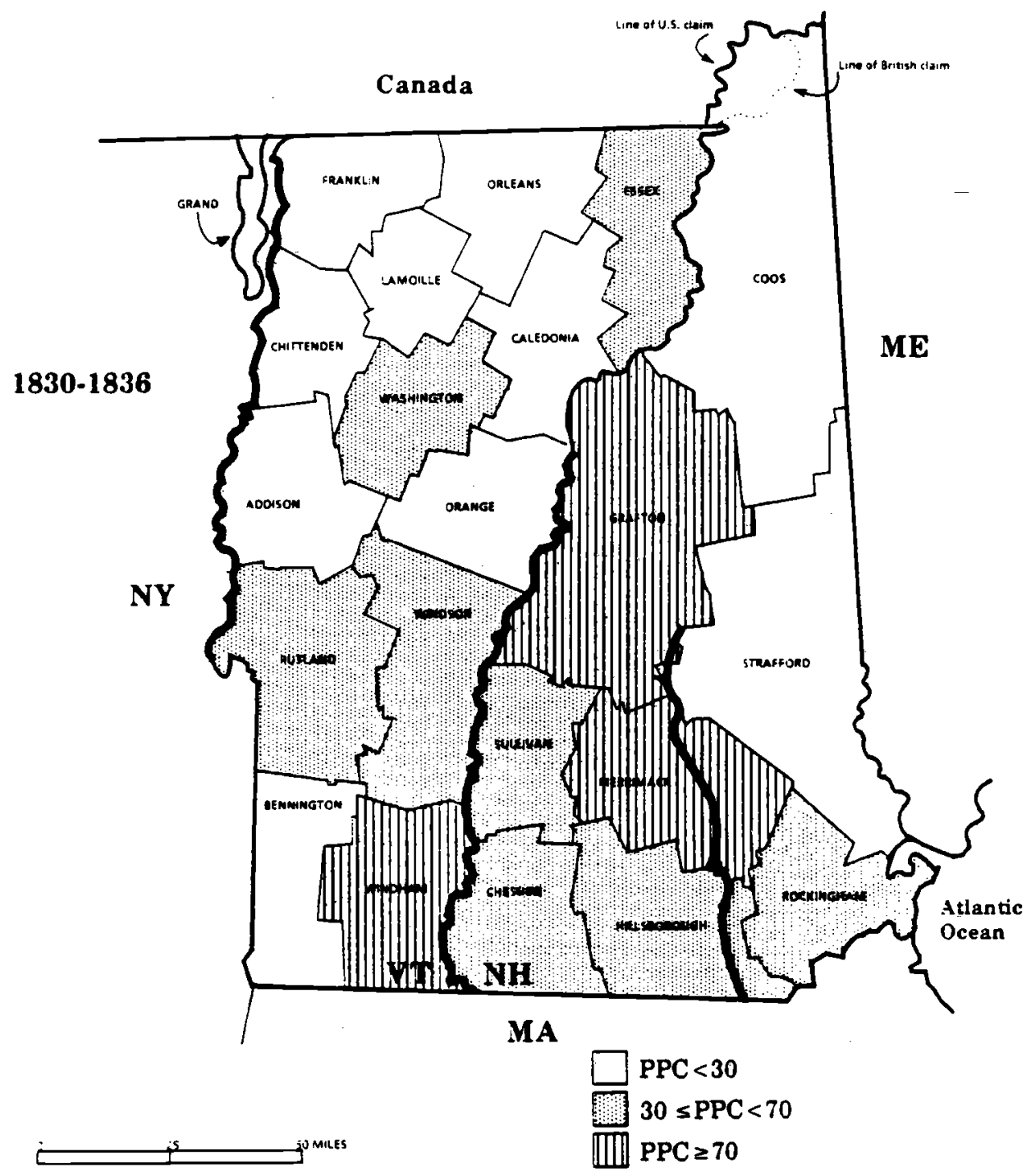


Notes and Sources to Figures 2 through 5 :

The maps were adapted from Williall Thorndale and William Dollarhide, Map Gulde to the Federal Censuses, $1790-1920$ (Baltimore, 1987). The major navigable inland waterways are inclicuted on the maps with bold lines, and were identified by consulting a variety of sources including Meyer, MacGill, et al., History of Transportation. Although the precise years at which particular stretches of waterways were made navigable are difficult to determine, the networks depicted on the inaps must be roughly correct. The shading of the individual counties reflects the respective estimates of levels of annual patents per million residents (or PPC). The only exceptions are a few counties in which the populations were so small that a very high PPC was achieved with only one patent being accounted for. These counties were given the interinediate shading, normally associated with a PPC equal to or greater than 30, but less than 70 . There are several cases in these figures in which the county boundaries presented for a sub-period, had not yet been put into piace. However, none of these involve districts which had elevated levels of patenting, and hence, the geographic patterns are unaffected. 
Merrimack Rivers, as well as one linking Lake Champlain to the Hudson, led to major increases in patenting in a number of the counties touched by the improvements. Simultaneous shifts in agricultural production, from an emphasis on grains to one on dairy products, hays, and livestock, also reflected the changes in relative prices and other demand conditions that accompany the integration of an outlying area into a large market. ${ }^{23}$

How does one account for the areas that do not experience much increase in patenting? In cases such as Pennsylvania, part of the explanation may be the scarcity of low-cost transportation, and the resulting insulation of much of the state from extensive markets. The state was endowed with rich deposits of coal and iron, but its mountainous terrain limited the number and extent of navigable waterways. Some rivers such as the Susquehanna were eventually cleared, but the exogenous circumstances of topography constrained the prospects for this sort of development much more than they had in neighboring New York. There are, in addition, the more puzzling districts that seem to have enjoyed access to navigable waterways, but did not realize significant gains in patenting per capita. All of Delaware, parts of New Jersey, and scattered counties in Pennsylvania and New York fall into this category. Here there is no obvious answer, other than that these exceptions deserve special scrutiny. Among the relevant features that seem worthy of investigation are the ethnicity and literacy of the population, as well as the suitability of ocean coastlines for ports. 24 Whatever the reasons for the dampened responses in these areas, the record suggests that low-cost transportation to market was a necessary rather than sufficient condition for high levels of inventive activity.

The cross-sectional variation is more systematically examined in the 
weighted regressions of patents per capita on county characteristics reported in Table 5 for 1805-1811, 1823-1829, and 1830-1836. The results demonstrate that the patterns of inter-regional differentials and the high rates of patenting in metropolitan centers noted above are statistically significant under multivariate analysis. Already by 1805-1811, Southern New England and New York produced far more patents per capita than Pennsylvania, New Jersey, or Delaware, even after adjusting for the composition of the labor force, urbanization, and modes of transportation. By 1823-1829, Northern New England joined the former areas in sharply increasing its patenting rate. Pennsylvania and its smaller neighbors also made progress over time, but, after controlling for other factors, continued to lag well behind the early leaders in 1830-1836. The coefficients estimated on these dumny variables for region reflect the influences of more fundamental contributors to patenting that are not otherwise captured by the independent variables. One should be cautlous in framing interpretations, but the persistence of the same general ranking of regions, and the intense creativity of metropolitan populations, support the implications of the simple averages reported above that there were salient location-related stimuli to invention that were slow to diffuse geographically. 25

The finding that most directly bears on the hypothesis that inventive activity was related to the level of market demand is the positive and statistically significant coefficient on the proxy for low-cost access to extensive markets - being located on a navigable river or canal. After controlling for region, urbanization, and the local distribution of the labor force, counties on navigable inland waterways realized levels of patents per capita that were well over 50 percent higher in all three 
Table 5

Cross-Sectional Regressions of Patents Per Capita on County Characteristics: 1805 $1811,1823-1829$, and $1830-1836$

Dependent Variable:

Log (Annual Patents Per Million Residents)

\begin{tabular}{lccc} 
& $1805-1811$ & $1823-1829$ & $1830-1836$ \\
\hline Constant & 1.397 & 1.724 & 2.429 \\
& $(4.61)$ & $(5.98)$ & $(8.21)$
\end{tabular}

Log
( $\left.\frac{\text { Manufacturing Labor Force }}{\text { Agricultural Labor Force }}\right)$
0.173
0.093
0.180
(1.21)
(0.79)
(1.58)

State Dummies:

Northern New England

0.166

(0.41)

0.707

(2.12)

1.001

2.041

(5.46)

1.826

(5.75)

(3.04)

Southern New England

0.891

1.535

(2.45)

(5.69)

1.489

New York

$-0.173$

Delaware or New Jersey

$(-0.35)$

$-0.400$

(4.47)

0.669

(2.56)

$(-0.93)$

$-0.716$

$(-1.62)$

Urbanization Dummies:

Urban

$-0.252$

$(-0.74)$

$-0.198$

$(-0.74)$

$-0.096$

2.205

1.831

(3.65)

$(-0.38)$

Metropolitan

(3.51)

1.183

(2.49)

Transportation Dummies:

Located on Navigable River or Canal

0.725

(2.26)

0.573

(2.18)

0.873

$-0.155$

$-0.426$

$(-0.39)$

$(-1.12)$

Located on Ocean

0.44

0.42

$(-0.13)$

$\mathrm{R}^{\mathbf{2}}$

132

174

0.35

N

174 
Notes and Sources:

These regressions were estinated over all northeastern counties existing at the beginning of the respective sub-periods for which the necessary information was available; the coefficients are reported with t-statistics below within parentheses. The observations were weighted by the populations estimated for the midpoints of the periods. The dumm variables for mode of transportation were coded such that a councy either had access to market through a navifable inland vaterway or by ocean; where the former was actually the case, the county was classified as having no access by ocean. The constant pertains to a rural county in Pennsylvania without immediate proximity to a navigable inland waterway or the ocean. Pooled cross-section regressions, with dummy variables for each of the time periods and relevant interactions, were also estimated. The qualitative results did not change, except that the coefficient on urban countles became positive and statistically significant. See the notes to the Appendix Tables 1 and 2 , as well as to figures 2 through 5 . 
sub-periods. Although the phenomenon is clearly complex, this strong positive association between patenting and proximity to navigable rivers and canals bolsters the hypothesis that there was an important link between integration into wide markets and inventive activity.

A straightforward interpretation of this finding is that the introduction of a population to immediate contact with an extensive market raised the level of inventive activity on a per capita basis either directly or indirectly. The direct effect entails individuals and firms choosing to commit additional resources to a search for useful discoveries in response to the increase in the expected return to such investment that stems from their integration into a larger pool of both potential customers and competing suppliers. A number of influences could be subsumed under indirect factors. For example, gaining low-cost access to a large market could alter behavior through changes in the prices of goods or in the returns to activities, and thus nurture cultural attitudes more favorable to invention, enhance learning-by-doing, improve the flow of information to potential inventors, raise the amount of resources available for allocation to invention, increase the propensity to invest in general, or foster such changes in methods or in the extent of factor specialization as to facilitate the discovery of possible refinements in technique or other inventions. All of these developments, as well as the improvement in the stock of knowledge arising from directly- or indirectly-induced invention, would help account for the patterns in the data.

Some information on the relative importance of these direct and indirect effects can be gleaned from the regressions, but the light shed should not be exaggerated. The relevant result is that the estimated 
relationship between inland waterways and patenting per capita is robust to the inclusion of another independent variable to control for the division of the labor force between agriculture and manufacturing. It tends to undercut the notion that the influence of access to market on inventive activity was exerted primarily through its indirect effect on the structure of production, such as growth in manufacturing. Indeed, it is striking that in these regressions, and in others estimated with alternative specifications, there is only a weak association between patenting and the sectoral distribution of the labor force at the county level after allowing for region, urbanization, and access to water transportation.

The cross-sectional evidence is thus consistent with the temporal patterns discussed above in suggesting the operation of a direct effect of market demand on inventive activity. Moreover, given that proximity to inland waterways captures only a single source of increase in the extent of market, and that it still accounted for a rather substantial increase in patents per capita, the economic significance of all such contributors together might seem assured. ${ }^{26}$ Although this exposition emphasizes the direct mechanisms, the apparent responsiveness of invention to the growth of markets is important regardless of the relative degrees of responsibility attributed to the direct and indirect effects. Both channels reflect how powerful the expansion of markets was in spurring the acceleration of economic growth during the initial phase of American industrialization.

Despite the mutual reinforcement provided by the temporal and cross-sectional evidence, skeptics might question the significance of, or causality behind, the latter. For example, it could be argued that the association between waterways and patenting influenced the geographic 
distribution of inventive activity, but had no effect on regional or national levels. In this view, individuals undertaking inventive activity chose to locate in those areas with low-cost access to broad markets, and would have merely been more concentrated geographically if the transportation grid had not been as extensive. This objection, however, appears inconsistent with the historical record. Not only does the interpretation offer no explanation of the substantial advances in patenting within regions or the country overall during the period, but it is contradicted as a general proposition by the many instances in which major growth in per capita activity was realized by counties with only modest population growth. 27

A more serious problem concerns the path of causation. Just as population settlement led the extension of midwestern railroads, it is possible that various changes in local economies encouraged the extension of inland waterways to serve the increased demand for such services. ${ }^{28}$ In theory, the cross-sectional relationship between high levels of patenting and inland water transportation could be explained in this way, but other evidence casts doubt on the view that this was the dominant mechanism at work. First, nearly all of the inland waterways under study were major northeastern rivers whose routes were exogenously determined; the chief exception, the Erie Canal, had its course specified by the state government in 1817 , during a severe economic contraction. 29

Moreover, the decisions to undertake the investments in water transportation considered here were generally settled during the first two decades of the nineteenth century, prior to any substantial sign of development in the affected areas. A close examination of the available 
data for the counties along the Erie Canal, for example, indicates that its construction clearly led any marked changes in patenting per capita or in the distribution of the labor force. ${ }^{30}$ No doubt the residents of affected districts supported the extension of waterways, but the overall record suggests that such projects were commonly initiated by governmental bodies concerned with broad goals and constituencies. This background to the expansion of waterways during the period supports my claim that the extension of these transportation routes increased rates of patenting and other types of economic change more than the reverse. 31

The conclusion that the extension of waterways did stimulate inventive activity invites the question of the quantitative significance of the contribution. Precise estimates are not feasible, but some rough calculations are reported in Table 6. Two distinct approaches are employed, and they yield similar results about the orders of magnitude in the Northeast. Method I, on which the A and B sets of figures are based, uses the coefficients from cross-sectional regressions to compute the net changes In patenting within geographic units that correspond to counterfactual expansions or contractions of the network of navigable inland waterways between 1805-1811 and 1830-1836. The A set of estimates, for example, suggests that after controlling for variables such as region, urbanization, and county labor-force allocation, levels of patenting would have been much higher in 1805-1811 if the grid of waterways in New England, New York, and Pennsylvania had been equivalent to that of 1830-1836. The figures imply that the proportional impact of the extension of the waterways after 1805-1811 was largest in Northern New England and Pennsylvania, with their totals of patents rising 49.1 and 26.7 percent respectively. By these 


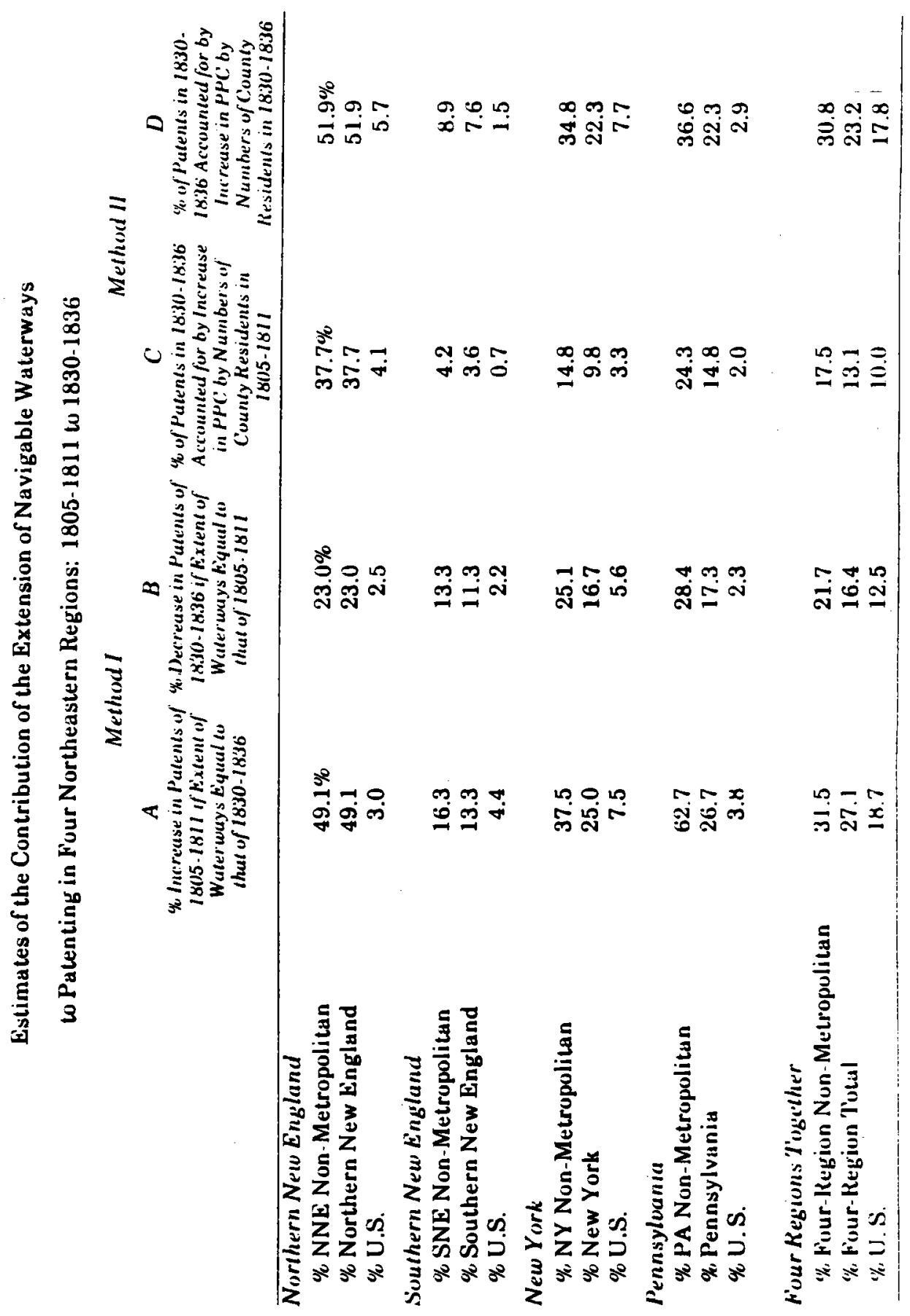




\section{Notes and Sources:}

Method I utilizes the coefficients from cross-sectional regressions (with the same specification as that employed in Table S, except with more disaggregated regional dunmies) to calculate the hypothethical effects of having a more extensive network of navigible watervays than existed in 1805-1811 (the A estimates) or of haring a lass extensive network in 1830-1836 (the B estimates). In this approach, the A estimates compute the implied effect of the additional waterways with the distribution of the population that existed without them held constant. The calculations were carried out by comparing the increments to patenting in the approprlate areas when the dummy variables for river/canal transportation were counterfactually raised from 0 to 1 or decreased from 1 to $O$ (in $A$ and $B$ respectively). These counterfactual fitted values were then computed to the "true" fitted values. By Method II, the $C$ and $D$ sets of estimates were computed by identifying those counties that gained access to navigable waterways after 1805-1811 but before 1830-1836. The increase in per caplta patents that was realized by each of these counties, or estimated for the relevant land area in cases where the county had not been established in 1805-1811, was then multiplied by the estimated county population or equivalent in 1805-1811, and the county population in 1830-1836 to construct the $C$ and $D$ figures respectively. Each of the resulting two sets of estimates of the incremental number of patents due to the extension of waterways were then summed across counties, and divided by the average annual number of patents awarded domestically during 1830-1836. See the notes to Appendix Tables 1 and 2 , as well as to Figures 2 through 5. 
estimates, the extension of the inland waterways in the four regions examined would alone have accounted for an 18.7 percent increase in U.S. patents per capita, nearly a quarter of the total advance between 1805-1811 and 1830-1836.

The B set of figures analogously estimates how much lower patenting would have been in 1830-1836 if the network of inland waterways had been restricted to that of 1805-1811. The proportional changes are uniformly smaller than in the A set, perhaps reflecting the spread of alternative modes of transportation that reduced the differentials in patenting between those counties with immediate access to such water routes and those without. Nevertheless, the qualitative result that the extension of waterways promoted more patenting, especially in Northern New England and Pennsylvania, is sustained.

The estimates obtained by Method II are computed by ascribing the entire increase in per capita patents between 1805-1811 and 1830-1836 in the relevant counties to the extension of navigable waterways during those 25 years. These advances in per capita rates are applied to the population totals for the counties in $1805-1811$ and $1830-1836$ to calculate a range of estimates of the proportions of the total patents emanating from the specified areas that can be accounted for by such improvements in transportation. For example, the $\mathrm{C}$ set holds the county populations at the 1805-1811 levels, and assumes that the observed increases in their patents per capita to 1830-1836 were attributable to the extension of the grid. The significance of improvements in waterways varies enormously between regions by these figures, ranging from rather minor in Southern New England to of major consequence in Northern New England. 
Even with the rather low population base underlying the $C$ estimates, 17.5 percent of the patents originating from non-metropolitan areas in the four regions together, 13.1 percent of all patents from the four regions, and 10.0 percent of national patents during 1830-1836 can be attributed to advances in waterways. These figures imply smaller effects on patenting than set $B$, which has the same 1830-1836 standard, but agree in suggesting that the extension of the inland waterways accounted for an important share of the growth in patenting during early industrialization. Set D applies the increases in per capita rates to the actual populations of the counties in 1830-1836, and accordingly yields even larger estimates.

By either method of estimation, therefore, the growth in patents accounted for by the extension of navigable waterways amounts to a significant fraction of the national total, a major share (in the 20-25 percent range) of the entire increase in U.S. patents per capita between 1805-1811 and 1830-1836, and even larger proportions of that increase in northeastern states. Since the analysis does not distinguish between the effects of extending the waterways and other factors correlated with them, there is admittedly a legitimate question about possible biases. Attributing all of the increase in patents per capita in counties along the routes to the waterways undoubtedly gives some credit where it is not due. Tending to offset this upward bias, however, is the lack of attention to other modes of transportation and the neglect of the stimulus of the expansion of the grid to invention in districts that had already enjoyed low-cost access to major markets by $1805^{32}$ 
The initial phase of industrialization in the American Northeast was a complex process, whose mechanisms are difficult to penetrate. Nevertheless, this analysis of systematic patterns in patent records has yielded some insight into the emergence of a greater commitment of resources to the search for better techniques and products - a change in behavior that is fundamental to sustained economic growth. First, in revealing that patenting on a per capita basis rose substantially in the Northeast during the first decade of the nineteenth century, and then resumed its acceleration after the War of 1812 and the postwar contraction, the evidence is consistent with the view that early industrialization was characterized by a dramatic upswing in inventive activity. Moreover, the timing of the event suggests that the Embargo of 1807 and other interruptions in foreign trade might indeed have served as a catalyst in promoting the expansion of the non-agricultural sector, increases in the extent and depth of markets, specialization of producers, invention, and technical change.

Although speculative, the outline emerging from this study is one in which a relatively prosperous pre-industrial population, which had a working knowledge of the current technology and was capable of learning from advances in Britain, responded strongly to a transformed economic environment. Given that competition was insured by the small scale of enterprise, individuals and firms sought to improve their production technique and develop new products as they became increasingly directed toward the pursuit of market opportunities. They committed much larger amounts of resources to inventive activity than previously, and the resulting stream of discoveries served to boost productivity, through the 
diffusion of the new methods or designs as well as the augmentation of the stock of knowledge for future invention. These developments were cumulatively important, if not profound, for the achievement of sustained growth.

The examination of the patterns in patenting revealed that inventive activity was quite concentrated in Southern New England and New York at the beginning of the century, and spread unevenly to the rest of the Northeast and the nation. Major urban centers stand out especially in having accounted for a highly disproportionate share of patents, but the majority of patents continued to be awarded to residents of non-metropolitan counties. With their dominant share, it was the increase in patenting by these latter areas that drove most of the national advance, and that has been the chief focus of attention here. Notwithstanding the obvious significance of factors such as slowly-evolving, location-specific conditions, changes in the stock of knowledge, and learning-by-doing, this analysis has highlighted the role of the expansion of markets in producing the acceleration of invention during this episode of early industrialization. Empirical support for this interpretation comes on several fronts. First, the marked cyclicality of patenting suggests that inventive activity was positively related to market demand. The critical role of growth or shifts in demand, in addition to mere access to the market, is further apparent in the experience of the metropolitan counties during the Embargo period. Although their residents had long enjoyed proximity to the market, and had received more patents than their counterparts elsewhere, Inventive activity seems to have soared in these urban centers during the years of disruption to trade. 
From another perspective, the cross-sectional analysis of the relationship between extent of market and patenting has also provided support for the hypothesis. The association uncovered between patenting and the local availability of water transportation is strong, and quantitatively important. Admittedly, one cannot necessarily infer the path through which access to transportation stimulated invention from this evidence alone, and a variety of indirect effects set off by the impact of transportation on development might contribute to the result. Yet the implications of both the cross-sectional and temporal patterns in patenting are that the direct incentives created by expanding markets did promote more invention. Regardless of the relative strengths of the different mechanisms involved, however, the findings suggest that the growth of markets during the early stages of industrialization diffused a powerful and long-term inducement to inventive activity, and in so doing, helped raise the realization of economic gains into a self-sustaining process. 


\section{FOOTNOTES}

1. Simon Kuznets defined inventive activity "as being concerned with technical inventions, i.e. new combinations of existing knowledge... potentially useful in economic production and resulting from a mental performance above the average." See Simon Kuznets, "Inventive Activity: Problems of Definition and Measurement," in Richard R. Nelson, ed. "The Rate and Direction of Inventive Activity (Princeton, 1962). Research on inventive activity is typically framed in terms of either the outputs produced or the inputs consumed in the process. The outputs yielded by inventive activity encompass the flow of new ideas, techniques, equipment, and products that are discovered and/or developed. The inputs include the costs of labor and other resources involved in the search for inventions. There appears to be a general consensus among economists who have analyzed modern patent data that there is a more regular relationship between the number of patents and the value of inputs to inventive activity than with the value of outputs; for example, see Ariel Pakes, "On Patents, $R$ D, and the Stock Market Rate of Return, " Journal of Political Economy, 93 (April 1985), PP. 390-409. This article is motivated by a concern with the circumstances under which individual households and firms came to commit much larger amounts of resources on a per capita basis to inventive activity, and the interpretations offered tend to be cast in terms of the allocation of resources. Nevertheless, the presumption is that, on average and over the period in question, the level of the outputs produced varied roughly with the consumption of inputs, and that the substantive implications of the findings are not sensitive to the perspective adopted.

2. Some recent examples of general histories of this genre are Thomas C. Cochran, Frontiers of Change: Earlv Industrialism In America (New York, 1981); Brooke Hindle and Steven Lubar, Engines of Change: The American Industrial Revolution, $1790-1860$ (Washington, D.C., 1986); David A. Hounshel1, From the American System to Mass Production, 1800-1932 (Baltimore, 1984); and Brooke Hindle, Emulation and Invention (New York, 1981).

3. See Jacob Schmookler, "The Level of Inventive Activity," Review of Economics and Statistics, 34 (Feb. 1954), PP. 183-90; Jacob Schmookler, Invention and Economic Growth (Cambridge, MA, 1966); and David S. Landes, The Unbound Prometheus: Technological Change and Industrial Development in Western Europe From 1750 to the Present (Cambridge, England, 1969). In the Kuznets tradition, Schmookler pioneered the systematic analysis of patent statistics for the purpose of studying inventive activity. Although recognizing the variety of experiences across industries, time, and specific inventions, he argued that the importance of demand, or the extent of the market, in altering the direction and level of inventive activity had not been well appreciated. He modeled the decisions of firms regarding the level of investment in inventive activity as a function of the expected gains from, and costs of, making a discovery. He argued that the extent or size of the market facing the firm was a major determinant of the expected gains, and investigated the relationship between patenting and proxies for the size of the market in many contexts. His work with time-series data on capital-good patents for a number of industries included the demonstration 
that the late-nineteenth and early-twentieth century trends in railroad patents of various types, such as those concerning rails, passenger cars,and freight cars, oscillated synchronously with the levels of investment in those types of capital equipment. Overall, Schmookler concluded that the expected profits from invention in particular industries were the prime determinants of the levels of invention in those areas, and that movements in the demand for the relevant products exerted substantial effects on the expected profits from invention. Landes employed similar ideas in his treatment of the onset of industrialization in Britain. Although most of his references were concerned with the invention in individual industries, he, like Schmookler, seemed to intend his framework to apply to both the direction and the level of general inventive activity.

4. Joel Mokyr has most directly challenged Landes's perspective on invention. See Joel Mokyr, "Demand vs. Supply in the Industrial Revolution," this Journal, 37 (December 1977), pp. 981-1008. Although Nathan Rosenberg generally does put more emphasis than Landes on supply-side factors, his studies of early nineteenth-century technology provide a rather balanced view when considered as a whole. Indeed, his attention to the extensive borrowing and modification of an already existing stock of British technology implies that the Americans did benefit from a substantial amount of less than fully exploited knowledge during the initial phase of their industrialization. In such a case, or when bottlenecks emerged, shifts in demand could have induced significant responses in inventive activity or patenting. See Nathan Rosenberg, "Technological Change in the Machine Tool Industry, 1840-1910," this Journal, 23 (December 1963), pp. 414-443;

Nathan Rosenberg, "Factors Affecting the Diffusion of Technology,"

Explorations in Economic History, 10 (Fall 1972), pp. 3-34; Nathan

Rosenberg, Technology and American Economic Growth (New York, 1972); and other essays in Nathan Rosenberg. Perspectives on Technology (Cambridge, England, 1976). Other works that deal with related issues include Paul A. David, Technical Choice. Innovation and Economic Growth: Essays on British and American Experience in the Nineteenth Century (Cambridge. England, 1975); and H. J. Habakkuk, American and British Technology in the Nineteenth Century: The Search for Labour-Saving Inventions (Cambridge, England, 1962).

5. See Kenneth L. Sokoloff, "Productivity Growth in Manufacturing During Early Industrialization: Evidence from the American Northeast, 1820-1860," in Stanley L. Engerman and Robert E. Gallman, eds., Long-Term Factors in American Economic Growth (Chicago, 1986); Kenneth L. Sokoloff, "Was the Transition From the Artisanal Shop to the Non-Mechanized Factory Associated With Gains in Efficiency?: Evidence From the U.S. Manufacturing Censuses," Explorations in Economic History, 21 (October 1984), pp.

351-82; and Winifred B. Rothenberg, "The Emergence of Farm Labor Markets and the Transformation of the Rural Economy: Massachusetts, 1750-1850, " this Journal, 48 (September 1988).

6. In contrast, those who argue for the supremacy of supply contend that the acceleration of invention stemmed from favorable developments on the cost side. In this view, technical breakthroughs in one area helped in the resolution of other technological problems, which in turn led to even further progress. If this were the major force behind the rise in invention at the outset of growth, one might expect the spurts of activity, and the associated gains in productivity, to be clustered in specific sets of industries. Inventions, whatever their source, alter the stock of 
knowledge, and that stock of knowledge surely affects both the conditions of supply and demand for goods, as well as the impact on further invention of shifts in demand. Given these complications, as well as the recognition that there is no general answer, it is obvious that the difficulties of empirically distinguishing between so-called demand and supply factors are formidable. With the circumscribed nature of the surviving evidence as an additional obstacle, it would seem nothing less than heroic to precisely estimate the quantitative significance of the two sets of variables in more than a few idiosyncratic cases. Nevertheless, it may be possible to obtain some notion of the orders of magnitude of their contributions during early industrialization. Moreover, such fine discrimination may not be required to determine whether or not inventive activity was highly responsive to the growth of markets, which may be the most important question concerning the phenomenon in this context.

7. Igniting creative energy is not exactly the appropriate metaphor. Humans have exhibited enormous creative energy and inventiveness throughout their history. However, much of it has always been directed towards pursuits that are not fully captured in our conventional measures of economic activity, such as the production or appreciation of art, the wooing of companions, schemes for redistribution, and the acquisition of status. Accordingly, although the total of all forms of inventiveness may indeed have increased substantially with industrialization, a metaphor that also encompasses the reallocation of creative energy might be more fitting. For further discussion of related issues, see Albert Hirschman, The Passions and the Interests: Political Arguments for Capitalism Before Its Triumph (Princeton, 1977).

8. A prominent exception to this generalization is Robert Higgs, "American Inventiveness, 1870-1920," Journal of Political Economy, 79 (May/June 1971), Pp. 661-667.

9. Since Schmookler's work, many scholars have used patent records to study inventive activity. See, for example, the papers in Zvi Griliches, ed. , $\underline{R}$ D. Patents, and Productivity (Chicago, 1984); and Nelson, ed., The Rate and Direction of Inventive Activity. The problems with such patent-based measures have been extensively discussed, but economists have generally come to accept them as useful indicators, especially of the inputs devoted to the inventive process. For example, see Pakes, "On Patents."

10. The sample was drawn from Henry L. Ellsworth, A Digest of Patents Issued By the United States From 1790 to January 1 . 1839 (Washington, D.C., 1840); and Edmund Burke, List of Patents For Inventions and Designs Issued By the United States From 1790 to 1847 (Washington, D.C., 1847). A machine-readable record of patents from this period is also being prepared by Robert R. MacMurray. See his "Technological Change in a Society in Transition: Work In Progress on a Unified Reference Work in Early American Patent History," this Journal, 45 (June 1985), PP. 299-303.

11. The real and relative value of this fee fluctuated substantially with marked swings in the price level. Nevertheless, one can be rather confident that the $\$ 35$ in current dollars represented at least 30 percent of per capita income throughout the period but seldom rose over 60 percent.

12. Discussions with Steven Lubar, Robert Post, and Deborah Warner of the Smithsonian Institution helped the author to make sense of the complicated history of the enforcement and administration of the patent system during the period, as did Lubar's recent paper, "Invention Becomes Enterprise: The Transformation of Patent Law in Antebellum America," 
unpublished manuscript, 1988. See also Robert C. Post, "'Liberalizers' versus 'Scientific Men'. in the Antebellum Patent Office," Technology and Culture, 17 (Jan. 1976), Pp. 24-54; Bruce W. Bugbee, Genesis of American Patent and Copyright Law (Washington, D.C., 1967); and Stacy V. Jones, The Patent Office (New York, 1971).

13. The classification of business or cyclical activity by year is drawn from Willard L. Thorp, Business Annals (New York, 1926). Similar information and judgments are provided by Walter B. Smith and Arthur $H$. Cole, Fluctuations in American Business, $1790-1860$ (Cambridge, Mass..

1935). Time-series regressions, estimated with dummy variables and interacted growth terms for years of recession and years of prosperity, yield statistically-significant evidence of cyclicality over annual data. However, the analysis of cyclicality in this article is based not on comparisons of individual years, but of years grouped together to identify sub-periods of "generally" consistent cyclical activity (such as

"prosperity" or "recession"). The principal deviations from this procedure include: the definition of the 1812-1822 sub-period, where the contraction of 1815-1822 was extended back three years because of the war being fought on U.S. territory; the classification of the 1805-1811 Embargo sub-period; and the division of 1836 at July 4th because of the change in the patent system. One is struck by the similarities in the cyclical patterns of patenting observed here and those noted by Schmookler. See his Invention and Economic Growth, chap. 6. In particular, he noted the high correlation between long-term trends in patenting and the expansion of the market, the salience of long swings in the growth of patenting, and the tendency of movments in patenting to slightly lag turning points in business cycles. His analysis relied on moving averages, as he too held reservations about the significance of short-term or year-to-year changes in patents.

14. The one episode that might appear to contradict the claim that patenting was positively related to cyclical activity is the sharp increase in the number of patents granted between 1805 and 1811 . In this sub-period, foreign trade was drastically reduced by a series of circumstances including the Embargo of 1807, and 3 of the 7 years are classified as ones of recession or depression. Although the spurt in patents defies conventional cyclicality, it may actually help establish the linkage between patenting and the state of the market. In particular, many narratives suggest that the suspension of foreign trade gave an enormous boost to domestic producers of manufactured goods and other items competing with imports. Hence, the stimulus to invention provided by this exogenous political development might be understood as arising from the vast proportional increase in demand for non-agricultural commodities and the associated advances in the specialization of producers and the extent of markets. These developments might reasonably have led to the growth of effective demand for producers of goods in areas like the Northeast, that enjoyed a domestic comparative advantage in non-agricultural commodities. With the limited market for domestic manufactures beforehand, the Embargo period might have begun with considerable unexploited knowledge and potential for learning-by-doing. From this perspective, it is perhaps not surprising that the sudden shifts in resources and concern with production for the market precipitated a spurt in patenting. See, for example, the discussions of the impact of the Embargo in Thomas C. Cochran and William Miller, The Age of Enterprise: A Social History of Industrial America (New York, 1961); Burton Spivak, Jefferson's English Crisis, 1803-1809; Commerce, Embargo, and the 
Republican Revolution (Charlottesville, 1979); and Claudia D. Goldin and Frank D. Lewis, "The Role of Exports in American Economic Growth During the Napoleonic Wars, 1793 to 1807," Explorations in Economic History, 17 (Jan. 1980), pp. 6-25. For evidence of increases in agricultural productivity and the market orientation of farmers in Southern New England during these years, see Rothenberg. "The Emergence of Farm Labor Markets."; Winifred B. Rothenberg. "The Market and Massachusetts Farmers, 1750-1855," this Journal, 41 (June 1981), PP. 283-314; and Winifred B. Rothenberg, "The Emergence of a Capital Market in Rural Massachusetts, 1730-1838," this Journal, 45 (December 1985), pp. 781-808. See Diane Lindstrom, Economic Development in the Philadelphia Region, 1810-1850 (New York, 1978), for a detailed discussion of the impact in eastern Pennsylvania. All of these fragments of the story lend support to the idea that an expansion of intra-regional specialization and trade within the Northeast, where all of the rise in per capita patents occurred, could have raised per capita income there as well as increased the size of markets facing potential inventors.

15. See the presentation of the model, and related discussion in Schmookler, Invention and Economic Growth, pp. 116-125.

16. For discussion of the greater severity in Southern New England and New York of the contraction of 1815-1822, see Cochran and Miller, The Age of Enterprise. For discussions of the many transportation investment projects undertaken during that contraction see the treatments in Balthasar Henry Meyer, Caroline E. MacGill, et al. History of Iransportation in the United States Before 1860 (Washington, D.C., 1917); Carter Goodrich, Julius Rubin, Jerome Cranmer, and Harvey Segal, Canals and American Economic Development (New York, 1961); and George R. Taylor, The Transportation Revolution, 1815-1860 (New York, 1962). Another posssible explanation of the appearance of dampened cycles in regions with lower rates of patenting per capita, such as the Southern Middle Atlantic and the Other U.S., is based on there being two components of patenting. One reflects a modest background level of inventive activity which was largely exogenous to the existence of a market, and the other represents a large market-responsive increment asssociated with a district's integration into a wider market. This structure implies that the higher the level of patenting within a geographic unit, the greater the proportion of inventive activity that was sensitive to national business conditions, and the more cyclically volatile the record should appear.

17. This feature of the record is not transparent because of the noise resulting from the small numbers of sample patents for the first two sub-periods, 1791-1798 and 1799-1804. After allowing for this problem, the stability of the national patent shares is striking. For example, in 1805-1811 and in 1843-1846, the proportion of patents classified as agricultural was the same, 19.2 percent; the proportion of manufacturing patents rises only slightly, from 44.7 to 47.1 percent. The surface stability in the national distribution of patents after 1805-11 appears to be largely the result of averaging across regions that were in different phases of a common transition and were growing at different rates. Although the signal in the data is weak, regions seem to have experienced an increase in the proportion of their patents that were agricultural when they underwent their first major spurt in inventive activity; as they developed further, the agricultural share declined. For example, when Southern New England realized its acceleration in patenting during 1805-1811, the agricultural and manufacturing shares amounted to 16.7 and 42.6 percent 
respectively; by the middle of the 1830 s, they had shifted to 7.9 and 56.3 percent. This process is visible in New York as well, but is screened in the national record by the relative growth of the other U.S. region and the later development of the rest of the Northeast. The stability is surprising, but is at least partially accounted for by patents having been classified on the basis of final use (where the latter was apparent). Accordingly, manufactured goods such as seed drills and ploughs are included in the agricultural category. More generally, however, agricultural invention might have flourished during the earliest stages of development in a region, because many farmers would have benefited from expansion in the market they faced and increasingly specialized in producing for that market, and because certain agricultural products were important inputs in manufacturing processes.

18. Again, the estimates of the distributions of the patents filed during 1791-1798 and 1799-1804 should be viewed with caution, because of the relatively few observations from those years.

19. Although some of the patterns observed may be due to variation over time or place in the inclination to patent, it seems unlikely that such hypotheses could provide a complete explanation. The most plausible of such arguments is that the inclination to register an idea with a patent might have been higher in big cities. However, the application procedure was relatively simple, and commonly described in broad-circulation periodicals of the time, until 1836. Moreover, it is not obvious as to how one might plausibly account for suitable cycles in inclination or culture. A related possibility is that the cycles in patenting were driven by movements in the real value of the patent fee, but the series on prices and patents do not conform well with it. For example, the number of patents rose sharply during the $1820 \mathrm{~s}$, while the price level plunged.

20. The interruptions in trade also had the effect of diverting the resources of urban merchants from foreign to domestic commerce. For further discussion of the relationship between patenting and urban centers, see Allan R. Pred, Urban Growth and the Circulation of Information: The United States System of Cities, 1790-1840 (Cambridge, Mass., 1973); and Higgs, "American Inventiveness."

21. Another example is Pennsylvania, where the rural and urban rates rose from 11.3 and 8.7 respectively to 38.1 and 31.4 between $1812-1822$ and $1830-1836$. Even with so many diverse counties grouped together, the early
advances in patenting are dominated by jumps, rather than growth along smooth continuous paths. This pattern is even more striking when one examines the records of individual counties separately. All counties in Northern New England are lumped together in the text here, because there were no metropolitan centers during this period, and generally no statistically significant differences between urban and rural counties in patenting.

22. The figures generally vary between 50 and 85 percent, depending on the time period and the regions compared. The results are strongest with Southern New England, where the metropolitan counties contain only a tiny fraction of the regional population.

23. The geographic extension of markets increases both competition and the size of markets for local producers; each effect could stimulate more invention. For discussions of the impact of the Erie Canal on household manufactures and production patterns in New York, see Rolla Milton Tryon, Household Manufactures in the United States, 1640.1860 (New York, 1917); 
and Arthur H. Cole, The American Wool Manufacture (Cambridge, Mass., 1926), Vol. I. For treatment of the changes in the agricultural sector of Northern New England, see Percy W. Bidwell and John I. Falconer, History of Agriculture in the Northern United States, 1620-1860 (Washington, D.C., 1941); and Percy W. Bidwell, "Rural Economy in New England at the Beginning of the Nineteenth Century," Transactions of the Connecticut Academy of Arts and Sciences, 20 (April 1916), pp. 241-399.

24. As indicated in the regressions reported below, there is no significant relationship across counties between bordering on the ocean and levels of patents per capita. The same types of regressions, when estimated with county-level literacy rates as an additional independent variable, indicate a strong positive relationship between literacy in 1840 , the first year for which such rates are avallable, and patenting during earlier sub-periods. The line of causation is not clear, however, since literacy in 1840 is only weakly correlated with patenting in 1836-1842 and 1843-1846. Further investigation is underway. The low levels of patenting in counties near Pittsburgh, and on major rivers in western Pennsylvania are somewhat puzzling. The latter pattern might stem from the indirectness of the water route to eastern cities.

25. Although the most straightforward explanation of this finding would probably focus on supply-side factors such as culture, ethnicity, occupational mix, and access to information or capital, some of these disparities in patenting across geographic units could plausibly be due to differences in the density, extent, or structure of markets not already captured by other independent variables.

26. The sizes of markets varied with population, per capita income, the dispersion of technology, the degree of factor specialization, as well as with business cycles and improvements in the transportation network. All of these factors may have spurred the growth of markets and inventive activity. Moreover, the apparent association between market size and patenting, the likelihood that the restriction of manufactures from abroad augmented the market for domestic producers, and the evidence that patenting soared during the relevant years suggest a significant role for the 1807 Embargo and other obstacles to foreign trade in igniting a sustained acceleration in invention and in productivity growth in the American Northeast. This view is consistent with recent findings concerning the record of productivity growth during the early nineteenth century. See Rothenberg, "The Emergence of Farm Labor Markets, "for evidence on labor productivity growth in agriculture during the early nineteenth century. See Sokoloff, "Productivity Growth in Manufacturing," for estimates of rapid progress in manufacturing between 1820 and 1860. The findings on patenting and productivity buttress each other in suggesting that many improvements in technique, accounting for substantial gains in productivity, were realized long before the broad wave of mechanization that occurred in the $1830 \mathrm{~s}$ and $1840 \mathrm{~s}$, and in relating these changes to the expansion of markets. Unfortunately, the evidence on manufacturing does not cover the Embargo sub-period, but the correspondence between increases in productivity and patenting between 1820 and the 1840 s, is consistent with the view that invention did augment productivity, and that variation in patenting does reflect variation in such activity.

27. An excellent example of previously outlying zones whose households altered their behavior in response to their becoming exposed to the forces of wider markets, is Northern New England during the $1820 \mathrm{~s}$ and $1830 \mathrm{~s}$. As 
improvements to rivers, such as the Connecticut, Kennebec, and Penobscot, were made over these years, patents per capita quadrupled. The populations of Maine, New Hampshire, and Vermont grew slowly over the interval, and it seems unlikely that a jump of this magnitude could be explained fully by the inflow of invention-prone migrants.

28. Albert Fishlow, American Railroads and the Transformation of the Ante-Bellum Economy (Cambridge, Mass., 1965), chap. 4.

29. See Carter Goodrich, Government Promotion of American Canals and Railroads. 1800-1900 (New York, 1960), chaps. 1 and 2; and Meyer et. al., History of Transportation, chap. 6.

30. For example, notice that the levels of patents per capita and the relative size of the manufacturing sector (as measured by the ratio of the manufacturing labor force to the agricultural labor force) are modest in the counties along the western half of the Erie Canal prior to its completion in 1825. Yet, major advances are apparent by the early 1830 s in patenting activity. It is also interesting that substantial increases in patents per capita were realized without large changes in the sectoral allocation of labor force. Some counties have no estimates for the earlier sub-periods, because they had not yet been carved out of the land areas of the others.

Annual Patents Per Million Residents Mfg. L.F./Agric. L.F.

$\begin{array}{lccccc}\text { County } & 1812-22 & 1823-29 & 1830.36 & 1820 & 1840 \\ \text { Cayuga } & 28.4 & 80.0 & 95.8 & 0.23 & 0.27 \\ \text { Wayne } & - & - & 72.0 & - & 0.29 \\ \text { Seneca } & 14.4 & 21.8 & 46.8 & 0.21 & 0.25 \\ \text { Ontario } & 18.8 & 11.6 & 83.8 & 0.11 & 0.25 \\ \text { Monroe } & - & - & 156.8 & - & 0.51 \\ \text { Orleans } & - & - & 61.4 & - & 0.15 \\ \text { Genesee } & 13.9 & 26.5 & 76.4 & 0.10 & 0.21 \\ \text { Niagara } & 11.8 & 214.6 & 71.9 & 0.08 & 0.17 \\ \text { Erie } & - & - & 122.6 & - & 0.33\end{array}$

31. In his study of wool manufacture, Cole came to the same conclusion about the direction of causation in the association between access to wide markets and the decline of household manufacture of woolens. As the network of navigable inland waterways was extended, more and more households came to alter their behavior in order to take advantage of the changed market environment:

... the home manufacture was 'becoming daily more exceptional.' And this could hardly be otherwise with the growth in the factory production, the cheapening and improvement of its output, and with the advent of better distributive and more adequate transportation facilities. The operation of these forces was so slow and inconspicuous that a picture of the movement cannot often be caught. However, the figures of household production in New York State, do give us an intimation of what 
must have been the experience of the country as a whole...

It is evident that in 1820 the counties nearer the City of

New York and those on the line of the Hudson River had already been affected by the domestic factory production or had been influenced by the importation of woolen goods; or contrariwise, the counties with the highest household manufacture were those located at some distance from the distributive centers.... By 1845, however, a curlous split had occurred. The counties of heaviest per capita production were now in the northern, less well-developed section of the state, or along the southern border. To one at all familiar with the history of transportation the reason is plain. In the interval between 1820 and 1845 the Erie Canal had been completed, and some portions of railroads reaching out westward from Albany, both traversing counties which had now ceased to have heavy per capita production. The introduction of transportation facilities occasioned a decay in the household industry.

Cole, The American Wool Manufacture, pp. 280-282.

32. It is interesting to note that Boston, New York City, and Albany, which were the metropolitan centers in the regions with the most extensive networks of navigable inland waterways, generally exhibited much higher levels of patenting per capita than did their counterparts in other regions. One might ask whether invention in such urban centers was somehow related to the volume of intra-regional trade. 


\section{Appendix Table 1}

Annual Patent Rates for Manufacturing Per 1,000,000 Residents, by Sub-Region

\begin{tabular}{|c|c|c|c|c|c|c|c|c|}
\hline & $\begin{array}{l}1791- \\
1798\end{array}$ & $\begin{array}{c}1799 . \\
1804\end{array}$ & $\begin{array}{l}1805 \\
1811\end{array}$ & $\begin{array}{l}1812 \\
1822\end{array}$ & $\begin{array}{l}1823 \\
1829\end{array}$ & $\begin{array}{l}1830- \\
1836\end{array}$ & $\begin{array}{l}1836- \\
1842\end{array}$ & $\begin{array}{l}1843- \\
1846\end{array}$ \\
\hline \multicolumn{9}{|l|}{ Northern New England } \\
\hline Rural & 0.0 & 3.4 & 5.3 & 6.9 & 11.2 & 22.6 & 9.7 & 4.7 \\
\hline Urban & -- & -. & 9.8 & 5.7 & 0.0 & 29.2 & 27.0 & 20.7 \\
\hline Metro & -. & -. & $-\cdot$ & -. & $-\cdot$ & -. & -. & .. \\
\hline TOTAL & 1.1 & 4.5 & 7.3 & 6.8 & 10.5 & 24.0 & 14.2 & 9.6 \\
\hline \multicolumn{9}{|l|}{ Southern New England } \\
\hline Rural & 1.4 & 2.6 & 27.4 & 26.6 & 30.2 & 38.8 & 27.6 & 15.3 \\
\hline Urban & 0.0 & 15.0 & 14.8 & 25.6 & 27.4 & 60.9 & 38.6 & 42.3 \\
\hline Metro & 11.9 & 19.6 & 145.8 & 120.0 & 71.1 & 109.8 & 93.1 & 171.3 \\
\hline TOTAL & 2.4 & 11.2 & 27.8 & 31.2 & 31.8 & 59.9 & 42.2 & 49.7 \\
\hline \multicolumn{9}{|l|}{ New York } \\
\hline Rural & 0.0 & 0.0 & 17.9 & 10.4 & 25.0 & 19.3 & 6.5 & 7.9 \\
\hline Urban & 0.0 & 0.0 & 13.9 & 17.5 & 49.0 & 22.4 & 9.7 & 30.9 \\
\hline Metro & 15.5 & 25.5 & 58.6 & 41.6 & 72.2 & 86.9 & 46.5 & 71.1 \\
\hline TOTAL & 6.0 & 5.6 & 26.6 & 17.5 & 37.7 & 32.2 & 15.8 & 32.2 \\
\hline \multicolumn{9}{|l|}{ Pennsyluania } \\
\hline Rural & 0.0 & 0.0 & 5.9 & 5.4 & 10.0 & 15.6 & 6.7 & 11.8 \\
\hline Urban & 0.0 & 8.6 & 0.0 & 3.3 & 2.1 & 11.5 & 5.0 & 8.3 \\
\hline Metro & 31.7 & 0.0 & 74.3 & 76.3 & 49.2 & 57.5 & 27.0 & 65.5 \\
\hline TOTAL & 7.0 & 10.0 & 16.2 & 15.5 & 13.9 & 21.3 & 9.7 & 20.0 \\
\hline \multicolumn{9}{|l|}{ Southern Middle Atlantic } \\
\hline Rural & 0.0 & 3.6 & 4.1 & 6.7 & 6.4 & 5.3 & 5.8 & 5.3 \\
\hline Urban & 4.8 & 11.9 & 0.0 & 10.3 & 3.0 & 4.5 & 8.0 & 30.3 \\
\hline Metro & 8.8 & 0.0 & 79.0 & 42.4 & 32.7 & 50.0 & 9.7 & 41.9 \\
\hline TOTAL & 2.2 & 8.8 & 12.3 & 13.2 & 10.4 & 14.1 & 7.8 & 19.5 \\
\hline Other $U . S$. & 0.0 & 2.2 & 1.0 & 2.0 & 3.0 & 4.0 & 2.2 & 2.7 \\
\hline NATIONAL AVERAGE & 2.0 & 5.7 & 10.7 & 9.7 & 12.5 & 16.1 & 8.7 & 12.9 \\
\hline
\end{tabular}


Appendix Table 2

Annual Patent Rates for Agriculture Per 1,000,000 Residents, by Sub-Region

$1791-1799-1805-1812-1823-1830-1836-1843-$

$\begin{array}{llllllll}1798 & 1804 & 1811 & 1822 & 1829 & 1836 & 1842 & 1846\end{array}$

\begin{tabular}{|c|c|c|c|c|c|c|c|c|}
\hline \multicolumn{9}{|l|}{ Northern New England } \\
\hline Rural & 0.7 & 0.0 & 1.5 & 4.0 & 9.5 & 17.8 & 6.0 & 2.3 \\
\hline Urban &.- & -. & 0.0 & 5.7 & 9.9 & 8.9 & 9.0 & 6.9 \\
\hline Metro & -. & -- & -- & $-\cdot$ & -. & $\cdots$ & $-\cdot$ & -- \\
\hline TOTAL & 0.7 & 1.9 & 2.2 & 4.1 & 9.6 & 15.8 & 6.3 & 3.5 \\
\hline \multicolumn{9}{|l|}{ Southern New England } \\
\hline Rural & 0.0 & 0.6 & 16.1 & 9.1 & 8.4 & 3.8 & 13.2 & 10.2 \\
\hline Urban & 0.0 & 0.0 & 4.9 & 2.9 & 4.8 & 8.8 & 11.8 & 2.0 \\
\hline Metro & 0.0 & 19.6 & 0.0 & 12.5 & 26.7 & 14.6 & 12.1 & 8.6 \\
\hline TOTAL & 0.0 & 1.3 & 10.9 & 6.5 & 7.9 & 8.4 & 12.6 & 4.5 \\
\hline \multicolumn{9}{|l|}{ New York } \\
\hline Rural & 0.0 & 0.8 & 15.1 & 11.4 & 11.3 & 20.5 & 2.5 & 2.2 \\
\hline Urban & 0.0 & 0.0 & 11.1 & 10.7 & 17.0 & 8.6 & 8.1 & 10.1 \\
\hline Metro & 0.0 & 13.0 & 9.9 & 17.9 & 25.9 & 23.8 & 9.5 & 21.6 \\
\hline TOTAL & 0.0 & 3.4 & 13.3 & 12.7 & 15.2 & 20.2 & 6.8 & 10.6 \\
\hline \multicolumn{9}{|l|}{ Pennsyluania } \\
\hline Rural & 0.0 & 0.0 & 1.7 & 3.2 & 3.9 & 11.7 & 5.6 & 3.9 \\
\hline Urban & 0.0 & 0.0 & 4.3 & 2.2 & 4.2 & 10.3 & 8.0 & 2.8 \\
\hline Metro & 6.3 & 0.0 & 10.8 & 7.2 & 23.2 & 10.8 & 4.8 & 3.1 \\
\hline TOTAL & 1.5 & 0.0 & 3.2 & 3.6 & 7.3 & 11.9 & 6.3 & 4.6 \\
\hline \multicolumn{9}{|l|}{ Southern Middle Atlantic } \\
\hline Rural & 0.0 & 2.4 & 1.7 & 4.1 & 4.0 & 4.6 & 15.3 & 0.0 \\
\hline Urban & 0.0 & 0.0 & 2.2 & 4.1 & 5.0 & 3.0 & .5 .8 & 6.7 \\
\hline Metro & 0.0 & 12.6 & 24.5 & 8.0 & 14.2 & 15.6 & 16.0 & 14.0 \\
\hline TOTAL & 0.5 & 3.8 & 4.6 & 4.7 & 6.5 & 6.8 & 14.8 & 4.7 \\
\hline Other U.S. & 0.5 & 0.2 & 1.5 & 1.4 & 4.1 & 3.6 & 1.7 & 4.4 \\
\hline NATIONAL AVERAGE & 0.5 & 1.3 & 4.6 & 4.2 & 6.9 & 8.3 & 4.6 & 5.2 \\
\hline
\end{tabular}


Notes and Sources:

The estimates of annual patents per million residents were obtained by treating the patents included in the sample as if they were representative of all of the patents issued in the respective sub-periods. The numbers of patents in the individual cells were inflated by the inverse of the proportion of total patents included in the sample. The sectoral classification is based on five sectors, with the miscellaneous category omitted from Tables 1 and 2 . The patents were categorized by final use when that was apparent, so patents concerning manufactured goods such as ploughs or harvesters were classified as agricultural patents. The population figures utilized for the estimates pertain to the mid-points of the respective sub-periods, where they were computed at the county level, with exponential growth between census years, and summed as appropriate. The small number of patents awarded to residents of foreign countries were omitted from the analysis. Although there were three patents issued in 1790, the estimates of patenting rates reported here do not begin until 1791, because there are no patents from the previous year included in the sample. Accordingly, the estimates are biased upward somewhat for the first sub-period. The dividing date between the 1830-1836 and 1836-1842 sub-periods is July 4,1836, when the new law went into effect. Northern New England includes Maine, New Hampshire, and Vermont; Southern New England includes Connecticut, Massachusetts, and Rhode Island; and Southern Middle Atlantic includes Delaware, New Jersey, Maryland, and the District of Columbia.

The indexes from which this sample was drawn contain both the city and state of residence for the holder of the patent in the great majority of 
cases, and especially after 1810. This infomation was utilized to classify each patent by county of residence in the particular year. The counties were categorized for urbanization in each census year, and the reported figures for urban and rural districts are based on a rolling set of counties. Metropolitan counties, however, are composed in all years of those counties that contained a city of 50,000 or greater in 1840; urban counties were those that contafned a city of at least 10,000 residents or were adjacent to a metropolitan county in the respective years. The observations without information on city of residence were included in the regional totals, but were generally not reflected in the estimates for classes of counties. This procedure does lead to some apparent inconsistencies or anomalies in the estimates, especially for the first two sub-periods, but seems the most sensible alternative. The only deviation from this practice was in New York, which was the only state in which there were significant numbers of such observations after 1810. Casual empiricism suggests that the great bulk of these patents were held by residents of New York City, and of the 100 such individuals whose residences could be traced through various means, approximately 81 percent were from New York City or Albany. Accordingly, such observations from New York were assigned to the metropolitan county class with a 0.81 probability in the construction of the estimates. 